\title{
Involvement of interleukin-1 type 1 receptors in lipopolysaccharide-induced sickness responses
}

DOI:

10.1016/j.bbi.2017.06.013

\section{Document Version}

Accepted author manuscript

Link to publication record in Manchester Research Explorer

\section{Citation for published version (APA):}

Matsuwaki, T., Shionoya, K., Ihnatko, R., Eskilsson, A., Kakuta, S., Dufour, S., Schwaninger, M., Waisman, A., Müller, W., Pinteaux, E., Engblom, D., \& Blomqvist, A. (2017). Involvement of interleukin-1 type 1 receptors in lipopolysaccharide-induced sickness responses. Brain, Behavior, and Immunity.

https://doi.org/10.1016/j.bbi.2017.06.013

Published in:

Brain, Behavior, and Immunity

\section{Citing this paper}

Please note that where the full-text provided on Manchester Research Explorer is the Author Accepted Manuscript or Proof version this may differ from the final Published version. If citing, it is advised that you check and use the publisher's definitive version.

\section{General rights}

Copyright and moral rights for the publications made accessible in the Research Explorer are retained by the authors and/or other copyright owners and it is a condition of accessing publications that users recognise and abide by the legal requirements associated with these rights.

\section{Takedown policy}

If you believe that this document breaches copyright please refer to the University of Manchester's Takedown Procedures [http://man.ac.uk/04Y6Bo] or contact uml.scholarlycommunications@manchester.ac.uk providing relevant details, so we can investigate your claim.

\section{OPEN ACCESS}




\section{Involvement of interleukin-1 type 1 receptors in lipopolysaccharide-induced sickness responses}

Takashi Matsuwaki $^{\mathrm{a}, \mathrm{b}}$, Kiseko Shionoya ${ }^{\mathrm{a}}$, Robert Ihnatko ${ }^{\mathrm{a}}$, Anna Eskilsson ${ }^{\mathrm{a}}$, Shigeru Kakuta ${ }^{\mathrm{c}}$, Sylvie Dufour ${ }^{\mathrm{d}}$, Markus Schwaninger ${ }^{\mathrm{e}}$, Ari Waisman ${ }^{\mathrm{f}}$, Werner Müller ${ }^{\mathrm{g}}$, Emmanuel Pinteaux ${ }^{\mathrm{g}}$, David Engblom ${ }^{\mathrm{a}}$, Anders Blomqvist ${ }^{\mathrm{a}}$ *

${ }^{\mathrm{a} D}$ Department of Clinical and Experimental Medicine, Linköping University, 58185 Linköping, Sweden

${ }^{b}$ Department of Veterinary Physiology, Graduate School of Agricultural and Life Sciences, The University of Tokyo, 1-1-1 Yayoi, Bunkyo-ku, Tokyo, 113-8657 Japan

${ }^{c}$ Department of Biomedical Science, Graduate School of Agricultural and Life Sciences, The University of Tokyo, 1-1-1 Yayoi, Bunkyo-ku, Tokyo, 113-8657 Japan

${ }^{\mathrm{d}}$ Institut Curie/CNRS UMR144, 75248 Paris, France

${ }^{\mathrm{e}}$ Institute of Experimental and Clinical Pharmacology and Toxicology, University of Lübeck, 23538

Lübeck, Germany

${ }^{\mathrm{f}}$ Institute for Molecular Medicine, University Medical Center of the Johannes Gutenberg University Mainz, 55131 Mainz, Germany

${ }^{\mathrm{g}}$ Faculty of Biology, Medicine and Health, University of Manchester, Manchester, M13 9PT, United Kingdom

32 pages, 7 figures

*Correspondence to Dr. Anders Blomqvist, Division of Neurobiology, Department of Clinical and Experimental Medicine, Linköping University, 58185 Linköping, Sweden. E-mail: anders.blomqvist@liu.se 


\begin{abstract}
Sickness responses to lipopolysaccharide (LPS) were examined in mice with deletion of the interleukin (IL)-1 type 1 receptor (IL-1R1). IL-1R1 knockout (KO) mice displayed intact anorexia and HPA-axis activation to intraperitoneally injected LPS (anorexia: 10 or $120 \mu \mathrm{g} / \mathrm{kg}$; HPA-axis: $120 \mu \mathrm{g} / \mathrm{kg})$, but showed attenuated but not extinguished fever $(120 \mu \mathrm{g} / \mathrm{kg})$. Brain $\mathrm{PGE}_{2}$ synthesis was attenuated, but Cox-2 induction remained intact. Neither the tumor necrosis factor- $\alpha$ (TNF $\alpha)$ inhibitor etanercept nor the IL-6 receptor antibody tocilizumab abolished the LPS induced fever in IL-1R1 KO mice. Deletion of IL-1R1 specifically in brain endothelial cells attenuated the LPS induced fever, but only during the late, $3^{\text {rd }}$ phase of fever, whereas deletion of IL-1R1 on neural cells or on peripheral nerves had little or no effect on the febrile response. We conclude that while IL-1 signaling is not critical for LPS induced anorexia or stress hormone release, IL-1R1, expressed on brain endothelial cells, contributes to the febrile response to LPS. However, also in the absence of IL-1R1, LPS evokes a febrile response, although this is attenuated. This remaining fever seems not to be mediated by IL-6 receptors or TNF $\alpha$, but by some yet unidentified pyrogenic factor.
\end{abstract}

Key words: Interleukin-1 type 1 receptor, lipopolysaccharide, fever, anorexia, ACTH, corticosterone, endothelial cells, TNF $\alpha$, interleukin- $6, \mathrm{PGE}_{2}$

\title{
Highlights
}

- IL-1R1 deletion reduces LPS-induced fever but not anorexia or HPA-axis activation

- IL-1R1s on brain endothelial cells are involved in the febrile response to LPS

- IL-1R1s on neural cells or peripheral nerves are not critical for LPS induced fever 


\section{Introduction}

Interleukin (IL)-1 $\beta$ is a potent inducer of sickness symptoms. When administered to animals it gives rise to fever, anorexia and stress hormone release (Berkenbosch et al., 1987; Dinarello et al., 1988; Hellerstein et al., 1989). It has also been shown to be critically involved in several human monogenic autoinflammatory syndromes that present systemic inflammatory symptoms such as fever (Jesus and Goldbach-Mansky, 2014).

The transducing receptor for IL-1 $\beta$, the IL-1 type 1 receptor (IL-1R1), is densely expressed on brain endothelial cells (Konsman et al., 2004; Liu et al., 2015; Matsuwaki et al., 2014), and systemic administration of IL-1 $\beta$ results in endothelial prostaglandin (PG) $\mathrm{E}_{2}$ synthesis (Ek et al., 2001), a mechanism that is likely to account for the febrile response to IL-1 $\beta$, since knock-down of the IL-1R1 as well as deletion of $\mathrm{PGE}_{2}$ synthesizing enzymes in brain endothelial cells attenuate IL$1 \beta$ induced fever (Ching et al., 2007; Wilhelms et al., 2014). However, IL-1R1 is also expressed on peripheral nerves, such as the vagus nerve (Ek et al., 1998), and a role for the vagus nerve in IL-1 $\beta$ induced fever has been reported (Gaykema et al., 2000; Turek et al., 2005; Watkins et al., 1995), therefore suggesting that IL-1 $\beta$ may induce central sickness symptoms both through a humoral and a neural pathway (Quan, 2014).

In light of the above data, it is surprising that genetic deletion of IL-1 $\beta$ or its transducing receptor has been reported to affect little if at all the sickness symptoms that are elicited by lipopolysaccharide (LPS), an immune stimulus that results in endogenous release of proinflammatory cytokines, including IL-1 $1 \beta$. Thus, mice with deletion of IL-1 $\beta$ not only show intact acute phase responses (Fantuzzi and Dinarello, 1996), but even display exaggerated fever and corticosterone release (Alheim et al., 1997). Furthermore, IL-1R1 knock-out (KO) mice have been reported to be fully responsive to the sickness inducing effects, including fever and anorexia, of systemically administered LPS (Bluthé et al., 2000; Leon et al., 1996), and no effect on the LPS induced stress hormone release was found in mice treated with an IL-1 receptor antagonist (Dunn, 
1992, 2000). However, conflicting data exist. Thus, treatment with an IL-1 receptor antagonist was reported to suppress LPS induced fever (Luheshi et al., 1996; Smith and Kluger, 1992) and mice with IL-1R1 deletion were reported to display attenuated fever to LPS (Labow et al., 1997). Moreover, animals deficient for IL-1RI have been shown to be completely resistant to LPS-induced mortality, suggesting an important role of this receptor in endotoxic shock (Aiura et al., 1991; Joosten et al., 2010; Ohlsson et al., 1990). Notably also, IL-1 $\beta$ is critical for the sickness responses to localized peripheral inflammation (Horai et al., 1998).

Considering the partly conflicting data on the effect of inhibition/deletion of the IL-1R1 for the LPS induced sickness response, and the fact that nothing is known about which IL-1R1 expressing cell type that may be involved, we re-examined this issue. We studied the effect of global gene deletion of IL-1R1 for LPS induced anorexia, stress hormone release and fever. While confirming that mice with deletion of IL-1R1 show intact anorexia and stress hormone release in response to immune challenge with LPS, we report that such mice display an attenuated febrile response, associated with attenuated central $\mathrm{PGE}_{2}$ levels. Because the febrile response was not completely abolished in the IL-1R1 KO mice, we examined the contribution of tumor necrosis factor- $\alpha(\mathrm{TNF} \alpha)$ and IL-6 receptor signaling to the temperature response. Furthermore, by using animals with cell/tissue specific deletion of IL-1R1, we examined the role of IL-1R1s in brain endothelial cells, neural cells or peripheral nerves related to IL-1R1 dependent fever.

\section{Materials and Methods}

\subsection{Animals}

Animals of both sexes, in approximately the same proportion, were used, and groups were balanced

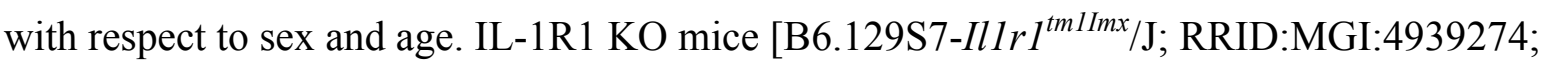
(Glaccum et al., 1997)] were obtained from the Jackson Laboratory (Bar Harbor, Maine) or provided by Dr. Yoichiro Iwakura, Tokyo University of Science. They were crossed once with wildtype C57BL/6 mice to generate heterozygotes. The heterozygous mice were then crossed with each 
other to generate of IL-1R1 KO mice and wild-type (WT) littermates, to be used for experiments. Mice with tissue-specific deletions of IL-1R1 were created by crossing mice possessing loxP sites flanking exon 5 of the Il1rl gene (Abdulaal et al., 2016) with mice expressing Cre recombinase under the Nestin promoter (expressed in the central and peripheral nervous system; B6.Cg- $\mathrm{Tg}(\mathrm{Nes}-$ cre)1Kln/J; RRID:IMSR_JAX:003771), the endogenous Trpv1 locus [expressed by nociceptors in primary sensory ganglia, as well as by some cell groups in the hypothalamus (Cavanaugh et al.,

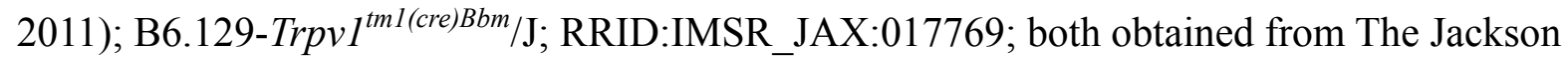
Laboratory], the human tissue plasminogen activator [HtPa; expressed by neural crest derivates (Pietri et al., 2003)], or a tamoxifen-inducible $\mathrm{CreER}^{\mathrm{T} 2}$ under the Slcolc1 promoter [expressed in the cerebrovascular endothelium (Ridder et al., 2011)]. Gene deletion in mice with the Slcolc1 $\mathrm{CreER}^{T 2}$ construct was induced by intraperitoneal injection of tamoxifen (1 mg tamoxifen diluted in a mixture of $10 \%$ ethanol and $90 \%$ sunflower seed oil twice a day for 5 d) at least 5 weeks before further experiments, as described previously (Eskilsson et al., 2014; Ridder et al., 2011). Control animals (WT) were for each experiments littermates obtained from the same breeding as that generating mice with the tissue specific deletion, i.e. they were offspring that had not inherited the gene encoding Cre recombinase and hence displaying intact $I l r l$ gene flanked by loxP sites. In the experiments generating mice with endothelial cells specific deletion, all animals, including the WT controls, were treated with tamoxifen. The animals were housed at one to four mice per cage on a 12-h light/dark cycle (lights on at $08.00 \mathrm{~h}$ ) with water and food available ad libitum, and at an ambient temperature of $22 \pm 1^{\circ} \mathrm{C}$, if not otherwise stated, with humidity between $30 \%$ and $40 \%$. All experimental procedures were approved by the Animal Care and Use Committee at Linköping University, being in accordance with the EU Directive 2010/63/EU for animal experiments, and followed the Guidelines for the Care and Use of Laboratory Animals, Graduate School of Agriculture and Life Sciences, the University of Tokyo, respectively. 


\subsection{Injection of LPS or saline and measurement of food intake}

Experiments were performed on global IL-1R1 KO mice and WT littermates of both sexes. One day before the immune challenge, the animals were housed at one mouse per cage. Food and water were removed $4 \mathrm{~h}$ before injection to increase feeding drive. LPS from Escherichia coli [SigmaAldrich, Saint Louis, MO; O111:B4; 10 or $120 \mu \mathrm{g} / \mathrm{kg}$ body weight; doses based on findings in previous studies (Elander et al., 2007; Nilsson et al., 2017)] diluted in $0.1 \mathrm{ml}$ saline, or saline only, was injected intraperitoneally (ip) $1 \mathrm{~h}$ before light-off. Food and water were returned to the cage $1 \mathrm{~h}$ after injection. Food intake was thereafter measured every $3 \mathrm{~h}$ during $24 \mathrm{~h}$, i.e. starting during the dark phase, when most food is consumed (Elander et al., 2007). Measurements were done manually by weighing the remaining food in the food tray. Visible food spillage in the cage was weighed and accounted for.

\subsection{Injection of LPS or saline and collection of brain and blood}

Experiments were performed on global IL-1R1 KO mice and WT littermates of both sexes.

Following ip injection of LPS $(120 \mu \mathrm{g} / \mathrm{kg}$, in $0.1 \mathrm{ml}$ saline $)$ or saline, at around $08.00 \mathrm{~h}$, mice were killed after 1,3 or $6 \mathrm{~h}$ by asphyxiation with $\mathrm{CO}_{2}$ and decapitated. The trunk blood was collected into heparinized tubes. After centrifuging, plasma was withdrawn and stored at $-20^{\circ} \mathrm{C}$ until further use. Immediately after blood collection, the brain was dissected out, fixed in $4 \%$ paraformaldehyde in phosphate-buffered saline (PBS) for $48 \mathrm{~h}$, soaked in a solution of $30 \%$ sucrose in PBS, and then processed for c-Fos or Cox-2 immunohistochemistry as described below.

\subsection{Hormone and cytokine assays}

Plasma corticosterone and IL-1 $\beta$ levels were determined by enzyme immunoassay. For corticosterone, a COTEIA corticosterone kit (Immunodiagnostic systems, Boldon, UK) with a minimum detection concentration of $0.55 \mathrm{ng} / \mathrm{ml}$ was used. For IL-1 $\beta$, a mouse IL-1beta /IL-1F2 Quantikine ELISA Kit (R \& D systems, Minneapolis, MN) with a minimum detection 
concentration of $12.5 \mathrm{pg} / \mathrm{ml}$ was used. The latter assay shows no cross-reactivity with IL-1 $\beta$ of other species or with other cytokines according to the manufacturer. For both assays, Four Parameter Logistic (4PL) curves were used and standard curves with an $r^{2}$ value of 1.00 were obtained. The plasma concentrations of adrenocorticotropic hormone (ACTH), TNF $\alpha$ and IL-6 were determined with a bead-based analysis kit (MBN1A-41K; Millipore, Billerica, MA), using the Luminex-100 system, as described in detail previously (Ruud and Blomqvist, 2007). The minimum detectable concentrations were $1.8,1.0$, and $0.6 \mathrm{pg} / \mathrm{ml}$ for ACTH, TNF $\alpha$ and IL-6, respectively.

\subsection{Immunohistochemistry}

Brain sections were cut in the frontal plane at $30 \mu \mathrm{m}$ on a freezing microtome, collected in cold cryoprotectant solution ( $0.1 \mathrm{M}$ phosphate buffer, $30 \%$ ethylene glycol, $20 \%$ glycerol), and stored at $-20^{\circ} \mathrm{C}$ until further use. Immunohistochemical staining was performed according to protocols described in detail previously (Engström et al., 2012). In short, for the staining for c-Fos or Cox-2, free-floating sections were pretreated with $0.3 \% \mathrm{H}_{2} \mathrm{O}_{2}$ in PBS for $30 \mathrm{~min}$, followed by $1 \% \mathrm{BSA}$ in

PBS for $2 \mathrm{~h}$, and then incubated in rabbit anti-c-Fos antibody (Ab-2; 1:5000; Millipore, Billerica, MA) in $0.3 \%$ Triton $\mathrm{X}-100$ in PBS (PBST) at $4{ }^{\circ} \mathrm{C}$ for $60 \mathrm{~h}$ or in rabbit anti-Cox-2 antibody (sc1747-R; 1:1000; Santa Cruz Biotechnology, Santa Cruz, CA) in PBST at room temperature overnight, and processed using a Vectastain ABC kit (Vector Labs, Burlingame, CA). Peroxidase activity was detected by incubation for $1-3 \mathrm{~min}$ in $0.5 \mathrm{mg} / \mathrm{ml}$ of 3, 3'-diaminobenzidine tetrahydrochloride (Sigma-Aldrich) dissolved in $0.1 \mathrm{M}$ Tris- $\mathrm{HCl}$, containing $0.01 \%$ hydrogen peroxide and $0.25 \%$ nickel ammonium sulfate.

\subsection{Injection of LPS and telemetric recordings of body temperature}

A transmitter (E-Mitter; Mini Mitter, Bend, OR) was implanted under isoflurane anesthesia into the peritoneal cavity 1 week before the immune challenge. Buprenorphine (Temgesic; $100 \mu \mathrm{g} / \mathrm{kg}$, in about $0.1 \mathrm{ml}$ saline subcutaneously; RB Pharmaceuticals, Sough, Berkshire, UK) was given for 
postoperative analgesia. Immediately after surgery, the mice were transferred to a room in which the ambient temperature was set at $29-30^{\circ} \mathrm{C}$, and housed at one mouse per cage. Body temperature was recorded every minute, starting $72 \mathrm{~h}$ prior to LPS injection. LPS (120 $\mu \mathrm{g} / \mathrm{kg}$ in $0.1 \mathrm{ml}$ saline) or saline only was injected ip at around $08.00 \mathrm{~h}$, and temperature responses hence recorded during the light phase to minimize activity related changes in body temperature. The dose of LPS was chosen on the basis of observations obtained in previous studies, showing that it results in robust fever (e.g. (Engström et al., 2012), without jeopardizing blood-brain barrier integrity (Banks et al., 2015). Inhibitors of cytokine signaling were administered as follows: etanercept (Enbrel; Amgen, Breda, Holland), a TNF $\alpha$ inhibitor, was given at a concentration of $10 \mathrm{mg} / \mathrm{kg}$ ip (in about $0.1 \mathrm{ml}$ saline) at the same time as the LPS injection; anakinra (Kineret; Wyeth, Dallas, TX), an IL-1 receptor antagonist, was given at concentration of $10 \mathrm{mg} / \mathrm{kg}$ ip (in about $0.1 \mathrm{ml}$ saline), $24 \mathrm{~h}$ before LPS injection; and tocilizumab (RoActemra; Roche, Mannheim, Germany), an IL-6 receptor antibody, was given at a concentration of $20 \mathrm{mg} / \mathrm{kg}$ subcutaneously (in about $0.05 \mathrm{ml}$ sesame oil), first 4 days before LPS injection and then at the same time as the LPS injection. Control animals were given saline or sesame oil only. All three drugs have been demonstrated to be effective in various experimental paradigms at similar doses (Aiura et al., 1993; Nilsberth et al., 2009; Ueda et al., 2013; Wakabayashi et al., 1991).

\section{7. $q P C R$}

The expression levels of Cox-1, Cox-2, mPGES-1, IL-1R1 and IL-6R $\alpha$ were determined in global IL-1R1 KO mice and their WT littermates by real-time PCR. The mice were decapitated $3 \mathrm{~h}$ or $6 \mathrm{~h}$ after injection of LPS or saline, and the hypothalamus was cut out. Total RNA was isolated by using TRIzol reagent (Invitrogen, Carlsbad, CA) according to the manufacturer's instructions, and $2 \mu \mathrm{g}$ from each sample was reverse-transcribed using oligo $(\mathrm{dT})_{16}$ primers (Perkin-Elmer, Boston, MA) and Superscript II (Invitrogen). Real-time PCRs were performed with Thunderbird SYBR qPCR MIX (TOYOBO, Osaka, Japan), a LightCycler (Roche, Mannheim, Germany), and the 
following primer pairs: 5'-CCTCTTTCCAGGAGCTCACA-3' (Cox-1 forward), 5'TCGATGTCACCGTACAGCTC-3' (Cox-1 reverse), 5'-GGGAGTCTGGAACATTGTGAA-3' (Cox-2 forward), 5'-GTGCACATTGTAAGTAGGTGGACT-3' (Cox-2 reverse), 5'GCACACTGCTGGTCATCAAG-3' (mPGES-1 forward), 5'-ACGTTTCAGCGCATCCTC-3' (mPGES-1 reverse), 5'-GTGCTACTGGGGCTCATTTGT-3' (IL-1R1 forward), 5'GGAGTAAGAGGACACTTGCGAAT-3' (IL-1R1 reverse), 5'ACAGAAGCAACGAGTGTCCTC-3' (IL-6R forward) and 5'-CAGAGAAGCAACCCAAACG-3' (IL-6R reverse). For normalization, the housekeeping gene hypoxanthine phosphoribosyltransferase (HPRT) was used as an internal control, using the following primer set: 5'-

\section{GACCGGTTCTGTCATGTCG-3' (forward) and 5'-ACCTGGTTCATCATCACTAATCAC-3'} (reverse). HPRT was selected as it is one of the most commonly used housekeeping genes, and its mRNA occurs in concentrations reasonably comparable to the mRNA of several of the target genes. It has successfully been used for examining LPS-induced gene expression in several tissues (MacParland et al., 2016; Medvedev et al., 2000). The Ct values were determined using the $2^{-\Delta \Delta \mathrm{Ct}}$ method.

\subsection{Assay for $P G E_{2}$ concentration in the cerebrospinal fluid}

Experiments were performed on global IL-1R1 KO mice and WT littermates of both sexes. Three and 6 hours, respectively, after injection of LPS or saline, the mouse was fixed in a stereotactic device under anesthesia with isoflurane. Neck muscles were divided in the midline to expose the atlanto-occipital membrane. Cerebrospinal fluid (CSF; 1-3 $\mu \mathrm{l})$ was collected from the cisterna magna by capillary effect using a glass pipette, and immediately frozen on dry ice. Samples that were contaminated with blood were discarded. The concentration of $\mathrm{PGE}_{2}$ in $\mathrm{CSF}$ was determined with a high sensitivity $\mathrm{PGE}_{2}$ enzyme immunoassay kit (Arbor Assays, Ann Arbor, MI), following the manufacturer's instructions. The assay range was $0.195-50 \mathrm{ng} / \mathrm{ml}$. 


\subsection{Statistical analyses}

Data were analyzed for differences between genotypes or treatments using a 2-way ANOVA (with genotype and treatment as main factors), or, for temperature data, a 2-way repeated measures ANOVA (with group and time as main factors), followed by Sidak's or Tukey's multiple comparisons tests, respectively (GraphPad Prism 6; GraphPad Software, San Diego, CA). $P<0.05$ was consider statistically significant. For tissue-specific KO mice, comparisons were made with WT littermates only, and never across different KO groups.

\section{Results}

\subsection{Normal inflammatory cytokine profile in IL-1RI KO mice}

We first examined the plasma levels and the immune-induced release of the pro-inflammatory cytokines IL-1 $\beta$, IL-6, and TNF $\alpha$ in IL-1R1 KO mice. There were no significant differences between the KO mice and their WT littermates with respect to plasma levels of these cytokines neither following LPS injection nor saline injection (Figure 1). The immune induced cytokine release followed the time course reported previously: A rapid increase in TNF $\alpha$, an intermediate IL6 response, and a slower IL-1 $\beta$ response (Elander et al., 2009). Hence, global deletion of IL-1R1 did not seem to affect neither the plasma levels of LPS induced pro-inflammatory cytokines, nor the time course of their release into the circulation.

\subsection{LPS induced anorexia and stress hormone release are unaffected in IL-1RI KO mice}

We next examined to what extent the major sickness symptoms anorexia, stress hormone release and fever that are elicited by LPS were affected by IL-1R1 deletion. To study anorexia, mice were injected ip with either a low $(10 \mu \mathrm{g} / \mathrm{kg})$ or a moderate $(120 \mu \mathrm{g} / \mathrm{kg})$ dose of LPS, and food intake was monitored during the following $24 \mathrm{~h}$. Both doses of LPS resulted in anorexia (Figure 2), although the anorexia was more pronounced after the higher dose. There was no difference in the anorexic response between IL-1R1 KO mice and their WT littermates. For the study of stress 
hormone release, animals were injected ip with LPS $(120 \mu \mathrm{g} / \mathrm{kg})$ and killed after $1 \mathrm{~h}, 3 \mathrm{~h}$, or $6 \mathrm{~h}$. There were no differences between genotypes with respect to neither ACTH nor corticosterone levels, both being strongly elevated by LPS (Figure 3A, B). Similarly, both WT and IL-1R1 KO mice showed prominent LPS induced expression of the activity marker c-Fos in the paraventricular hypothalamic nucleus (Figure 3C).

\subsection{IL-1RI deletion/inhibition attenuates the febrile response to LPS}

Thus, whereas anorexia and stress hormone release in response to LPS were unaffected by deletion of the IL-1R1, a clear difference was seen in the febrile response between groups $\left(F_{2,21}=17.56 ; P\right.$ $<0.001$, for the period of 180-480 min). In WT mice, intraperitoneal injection of LPS $(120 \mu \mathrm{g} / \mathrm{kg})$ resulted in a febrile response that peaked at about $5 \mathrm{~h}$ post injection (Figure 4A). In contrast, in IL1R1 KO mice the response to LPS was strongly attenuated $(P<0.05-0.001$ for $241-368$ min post LPS injection; Figure 4A). Nevertheless, from about $5 \mathrm{~h}$ post injection, the body temperature of LPS treated IL-1R1 KO mice was higher than that displayed by saline injected mice of the same phenotype $(P<0.05-0.001$ for 343-480 min; Figure 4A), implying that IL-1R1 deletion did not completely abolish the febrile response to LPS. Since this lingering response conceivably could be due to some compensatory mechanism in the gene deleted mice, we also examined the febrile response in WT mice treated with the IL-1 receptor antagonist anakinra $(10 \mathrm{mg} / \mathrm{kg})$ given ip $24 \mathrm{~h}$ before the LPS injection (Figure 4B). However, similar to the IL-1R1 gene deletion, pharmacological inhibition of IL-1R1 with anakinra attenuated the febrile response, but did not abolish it [Group factor: $F_{2,18}=11.64 ; P=0.006$; for the period of $180-420 \mathrm{~min} . P<0.05-0.01$ for anakinra + LPS vs. vehicle + LPS, and $P<0.05-0.001$ for anakinra + LPS vs. anakinra + saline, at various time points (see Figure 4B)]. 
3.4. Neither TNFa inhibition nor IL-6 receptor blockade abolish the LPS induced febrile response in IL-1R1 KO mice

We next examined the contribution of TNF $\alpha$ and IL-6 respectively to the febrile response in IL-1R1 KO mice. After treatment with the TNF $\alpha$ inhibitor etanercept, LPS evoked an augmented febrile response, which was statistically significant for IL-1R1 KO mice [2-way ANOVA; group factor: $F_{3,34}=7.084 ; P=0.0008$, for the period of $180-480$ min post LPS injection; etanercept treated vs. saline treated IL-1R1 KO mice injected with saline: $P<0.05-0.01$ for various time points (see Figure 5A)], but a similar tendency was seen in WT mice (Figure 5A). Administration of the IL-6 receptor antibody tocilizumab resulted in a tendency to attenuated fever in WT mice (Figure 5B), and although this response was not statistically significant, it is well in line with the pyrogenic role of IL-6 receptor signaling (Eskilsson et al., 2014), and with the absence of fever after genetic or pharmacologic inhibition of IL-6 (Cartmell et al., 2000; Chai et al., 1996; Kozak et al., 1998; Nilsberth et al., 2009). In contrast, no such tendency was seen in IL-1R1 KO mice, which is consistent with a previous demonstration that the pyrogenic action of IL-6 is dependent on the presence of IL-1 $\beta$ signaling (Cartmell et al., 2000). Neither etanercept nor tocilizumab had any effect on the body temperature in WT or IL-1R1 KO mice that were injected with saline (data not shown). Taken together, these data suggest that neither TNF $\alpha$ nor IL-6, at least as present in plasma, contribute to the febrile response in IL-1R1 KO mice.

\subsection{Endothelial cell deletion of IL-1R1 attenuates LPS induced fever}

Because $\mathrm{PGE}_{2}$ synthesis in endothelial cells is critical for LPS induced fever (Engström et al., 2012; Wilhelms et al., 2014), and because IL-1R1s are heavily expressed by endothelial cells (Konsman et al., 2004; Liu et al., 2015; Matsuwaki et al., 2014; Vasilache et al., 2015), we examined the role of brain endothelial cell IL-1R1 for LPS induced fever. To this end, we used mice with inducible deletion of IL-1R1 on endothelial cells (IL-1R $\left.1^{\Delta \mathrm{Slcolc1} 1}\right)$, generated by crossing mice with a tamoxifen-inducible CreER $^{\mathrm{T} 2}$ under the Slcolcl promoter [expressed in the 
cerebrovascular endothelium (Ridder et al., 2011)] with mice with conditional deletion of IL-1R1 (Abdulaal et al., 2016). Like mice with global deletion of IL-1R1, IL-1R ${ }^{\Delta \text { Slcolc1 }}$ mice showed attenuated febrile response to ip injection of LPS, but only during the late, $3^{\text {rd }}$ phase, of fever (starting at 240 min post LPS injection) (2-way ANOVA; group factor: $F_{2,56}=52.77 ; P<0.0001$, for the period of 240-480 min; $P<0.05$ for WT LPS vs. KO LPS for various time points, see Figure 6A), whereas in the global IL-1R1 KO mice a tendency towards attenuated fever was seen also at earlier time points (Figure 4A).

\subsection{IL-1R1s on neural cells or peripheral nerves plays little if any role for LPS induced fever}

In addition to endothelial cells, IL-1R1s are expressed by sensory nerves, which have been shown to respond to IL-1 $\beta$ both in vivo and in vitro (Binshtok et al., 2008; Ek et al., 1998). We examined the role of IL-1R1s on neural structures for the LPS induced febrile response using mouse lines expressing Cre recombinase under the Nestin promoter (expressed both in the central and peripheral nervous system) (Figure 6B), the human tissue plasminogen activator [HtPa, expressed by neural crest derivates (Pietri et al., 2003)] (Figure 6C), or the endogenous Trpv1 locus [expressed by nociceptive primary afferent nerves (Cavanaugh et al., 2011)] (Figure 6D). However, these cell/tissue specific deletions of IL-1R1 had little if any effect on the temperature response to LPS, with the possible exception of the gene deletion in the IL-1R $1^{\Delta \text { Nestin }}$ mice, which displayed a somewhat attenuated response during the second phase of fever (120-240 min post LPS injection) (2-way ANOVA; $F_{2,49}=10.09 ; P=0.0002$, for group effects for the period of 120-240 min; LPS treated WT mice vs. LPS treated IL-1R $1^{\Delta \text { Nestin }}$ mice: $P<0.05$ for various time points, see Figure $6 B)$.

3.7. Deletion of IL-1RI attenuates LPS induced PGE 2 release into the cerebrospinal fluid but not Cox-2 expression in the hypothalamus

Examination of the $\mathrm{PGE}_{2}$ concentration in the cerebrospinal fluid after immune challenge with LPS 
showed that $\mathrm{PGE}_{2}$ levels increased in both WT and IL-1R1 KO mice treated with LPS, with lower $\mathrm{PGE}_{2}$ levels in IL-1R1 KO mice than WT mice (Figure 7A). While LPS-induced induction of $\mathrm{PGE}_{2}$ levels was most pronounced at $6 \mathrm{~h}$ post injection, the difference between genotypes was statistically significant at $3 \mathrm{~h}$ post injection (group x treatment $F_{1,22}=6.291 ; P=0.02$. WT vs. KO: $P=$ 0.0032). Surprisingly, however, Cox-2 (Ptgs2) mRNA expression (as examined in the hypothalamus) was induced to similar levels in both genotypes (Figure 7B), and both genotypes also displayed abundant expression Cox-2 protein in the cerebral vessels (Figure 7C). In the dataset shown in figure 7B, Cox-2 mRNA expression was in fact higher in IL-1R1KO mice than in WT mice at $3 \mathrm{~h}$ post LPS injection (group x treatment: $F_{1,22}=10.95 ; P=0.0032$. WT vs KO: $P=$ 0.004), contrary to what was hypothesized. However, when the analysis was repeated in an independent experiment no difference between the genotypes was found (data not shown). There was no difference in the expression of Cox-1 (Ptgs1; Figure 7D) or mPGES-1 (Ptges; Figure 7E) in the hypothalamus between genotypes (with mPGES-1 but not Cox-1 being regulated by LPS; Figure 7E). The IL-6 receptor alpha was induced by LPS and to the same extent in WT and IL-1R1 KO mice (Figure 7F). Also, IL-1R1 expression was induced by LPS (in WT mice; to about the twice the basal level), as shown previously (Matsuwaki et al., 2014).

\section{Discussion}

The results of present study show that IL-1 receptors are involved in the febrile response, but not in the anorexia and stress hormone release, evoked by peripheral immune challenge with LPS. The temperature response to LPS was monitored during the light phase to minimize activity related changes in body temperature, and so was also HPA-axis activation (Fos expression in the PVH, and ACTH and corticosterone release), whereas food intake was measured after LPS had been injected immediately prior to the dark phase during which mice consume most of the food (Elander et al., 2007). While this strategy is well-established for studies of fever and anorexia, it implies that the endpoints were evaluated at different time points during the light cycle, and the data should hence 
be interpreted with the qualification that the duration and magnitude of the sickness responses do not differ between WT and IL-1R1 KO mice as a function of the time of the day (cf. Morrow and Opp, 2005). It should also be noted that whereas food intake data were analyzed both after a low $(10 \mu \mathrm{g} / \mathrm{kg})$ and a moderate dose $(120 \mu \mathrm{g} / \mathrm{kg})$ of LPS, the fever and HPA-axis responses were recorded after the moderate dose of LPS only. Because different doses of LPS may engage distinct immune-to-brain signaling routs differently (Quan, 2014), the present results may be dependent on the LPS-dose chosen.

The attenuation of fever in IL-1R1 KO mice was particularly prominent between 4-6 $\mathrm{h}$ after LPS injection. This observation fits with the time course for the release into plasma of IL-1 $\beta$, which displayed elevated levels at $3 \mathrm{~h}$ and $6 \mathrm{~h}$ post injection, but not at $1 \mathrm{~h}$, as also shown previously, using a similar experimental paradigm (Elander et al., 2009). It is hence consistent with the idea that fever occurs as a consequence of humoral signaling to brain endothelial cells, which display cytokine receptors and possess the machinery for the synthesis of pyrogenic $\mathrm{PGE}_{2}$ upon peripheral immune challenge (Ek et al., 2001; Yamagata et al., 2001), a concept that was recently verified in functional studies (Eskilsson et al., 2014a; Wilhelms et al., 2014). Furthermore, we here show that IL-1R1s expressed by brain endothelial cells are involved in the LPS induced fever, whereas IL1R1s on neural cells or peripheral nerves plays little if any role. Notably, after deletion of IL-1R1s specifically in brain endothelial cells, which are exposed to circulating IL-1 $\beta$ levels, attenuation of fever was seen only during the late phase of the response ( $>4 \mathrm{~h}$ post injection), again being in line with the release kinetics of IL-1 $\beta$.

The presence of a residual temperature elevation in the IL-1R1 KO mice after LPS challenge suggests that other factors than IL- $1 \beta$ contribute to the febrile response. Here we examined the contribution of TNF $\alpha$ and IL-6 by using neutralizing or receptor blocking antibodies, respectively. In agreement with what has been reported previously (Kozak et al., 1995; Leon et al., 1998; Long et al., 1990a; Long et al., 1990b; Tollner et al., 2000), we found that endogenous TNF $\alpha$ is 
cryogenic, since its inhibition with etanercept increased LPS induced fever. This effect of etanercept was statistically significant in IL-1KO mice, implying that the cryogenic effect of TNF $\alpha$ is independent of IL-1 $\beta$ signaling. IL-6 receptor blockade with tocilizumab showed a tendency to attenuate LPS induced fever, but did so only in WT mice and not in IL-1R1 KO mice. The latter observation is in line with the finding that IL-6 is not or only weakly pyrogenic per se (Nilsberth et al., 2009; Rummel et al., 2006), but requires concomitant IL-1 $\beta$ signaling to elicit a febrile response. Thus, it was shown that IL-6 elicited fever only when co-injected with a non-pyrogenic dose (when given alone) of IL-1 $\beta$, and exacerbated the fever to a pyrogenic dose of IL-1 $\beta$ (Cartmell et al., 2000; see also Harden et al., 2008). The absence of a temperature lowering effect of IL-6 receptor inhibition in IL-1R1 KO mice imply that the residual temperature elevation seen after LPS in these mice was not IL-6 mediated.

In a study using endothelial specific knock-down of IL-1R1 it was found that while this procedure abolished the febrile response to iv injected IL-1 $\beta$, it only attenuated and delayed the response when IL-1 $\beta$ was injected ip (Ching et al., 2007), an observation similar to that seen in the present study following ip injection of LPS in IL-1R1 KO mice. The authors suggested that their finding be explained by IL-1 $\beta$ activation of the central nervous system via a pathway independent of IL-1R1 on endothelial cells, such as IL-1R1 on peripheral nerves. However, if the mechanism is similar to that by which ip injected LPS induces fever in IL-1R1 KO mice, it may involve the induced release of other cytokines/chemokines that act on the brain independently of IL-1R1. The long delay before fever appeared favors such an interpretation. Along this line, some of the remaining responses to immune challenge in IL-1R1 KO mice might be ascribed to a truncated IL1R1 variant, named IL-1R3, that is present in neural tissues and found in the IL-1R1 KO strain used in the present study (Qian et al., 2012). However, while this receptor has been shown to mediate electrophysiological responses to IL-1 $\beta$ in transfected cells (Qian et al., 2012), its role for behavioral responses to immune stimuli needs to be demonstrated. 
In agreement with the attenuation of LPS induced fever in IL-1R1 KO mice, these mice also showed attenuated $\mathrm{PGE}_{2}$ levels in the cerebrospinal fluid. Surprisingly, there was no difference between WT mice and IL-1R1 KO mice with respect to Cox-2 mRNA levels in the hypothalamus, and both genotypes showed abundant Cox-2 expression in brain vascular cells. While these data suggest the presence of some post-translational regulation of Cox-2 (Mbonye and Song, 2009), it is also important to consider that $\mathrm{PGE}_{2}$ levels in the cerebrospinal fluid do not necessarily reflect the prostaglandin synthesizing capacity in the hypothalamus, as we recently demonstrated (Eskilsson et al., 2017). Furthermore, the present observations imply that LPS induced cerebral Cox-2 induction is not dependent on IL-1R1, but is elicited by some other factor. However, in the present experimental paradigm it is probably not IL-6. Although IL-6 receptor signaling has been shown to be critical for Cox-2 expression in the brain endothelium upon peripheral immune challenge with LPS (Eskilsson et al., 2014), IL-6 per se, without concomitant IL-1 signaling, is unable to elicit Cox-2, or to increase brain $\mathrm{PGE}_{2}$ levels, consistent with its inability to elicit fever (Nilsberth et al., 2009a). Exogenously administered TNF $\alpha$ evokes Cox-2 in the brain vasculature (Cao et al., 1998), and is accordingly a possible candidate for the Cox-2 expression seen in LPS challenged IL-1R1 KO mice. However, exogenous TNF $\alpha$ evokes fever (Cao et al., 1998) in contrast to endogenous $\mathrm{TNF} \alpha$, which is cryogenic, and it is hence not clear if TNF $\alpha$, when released endogenously, will elicit Cox-2 expression in brain vascular cells. Still another possibility would be that LPS by itself, through binding to $\mathrm{TLR}_{4}$ on brain vascular cells (Chakravarty and Herkenham, 2005), may evoke Cox-2 expression, and also account for the residual temperature elevation seen in LPS challenged IL-1R1 KO mice (Dinarello, 2004). However, TLR 4 expression, while abundant in perivascular cells of the brain blood vessels, is sparse in the brain endothelial cells (Vasilache et al., 2015), the Cox-2 expression of which is critical for fever (Engström et al., 2012; Wilhelms et al., 2014).

IL-1 $\beta$ is known as a potent anorexigen (Hellerstein et al., 1989) and activator of the HPA-axis (Berkenbosch et al., 1986; Besedovsky et al., 1986). Yet, pharmacological blockage or genetic 
deletion of IL-1R1 failed to reduce the anorexia and stress hormone release elicited by LPS (Bluthé et al., 2000; Dunn, 1992, 2000; Leon et al., 1996), as also demonstrated in the present study. These observations imply that while exogenously administered IL-1 $\beta$ is sufficient to elicit anorexia and HPA-axis activation, endogenously produced IL-1 $\beta$ is either only a redundant component behind these responses to peripheral immune challenge, or not involved at all. Notably, however, the stress hormone release to psychological stress is attenuated in IL-1R1 KO mice (Goshen et al., 2003), which is in line with the finding that immune stress and psychological stress, respectively, elicit dissimilar transcriptional profiles in the paraventricular nucleus of the hypothalamus (Reyes et al., 2003), suggesting that they are mediated by distinct signaling pathways.

IL-1R1 on peripheral nerves, such as the vagus nerve, has long been implicated in the febrile response. It has been reported that subdiaphragmatic vagotomy attenuates IL-1 induced fever (Gaykema et al., 2000; Turek et al., 2005; Watkins et al., 1995; but cf. Konsman et al., 2000; Luheshi et al., 2000), and it has also been reported that the vagus nerve may be involved in LPS induced fever (Romanovsky, 2000). However, in the present study there was no effect on the temperature response to LPS in mice with deletion of IL-1R1 specifically on TRPV1 expressing structures, such a thin afferent nerve fibers (Cavanaugh et al., 2011), or on tissue derived from the neural crest, suggesting that binding of endogenously produced IL-1 $\beta$ to IL-1R 1 on peripheral nerves is not critical for LPS induced fever. However, it should be noted that some previous studies have suggested that a neuronal route of immune-to-brain communication might play a role only when robust amounts of circulating cytokines are absent (Quan, 2014; Ross et al.; Rummel et al., 2005). Because considerable amounts of cytokines are released into the circulation in the present experimental model (Fig. 1), it is conceivable that a contribution of sensory nerves could have escaped detection.

In the brain, IL-1R1 is demonstrated by immunohistochemistry to be present exclusively on endothelial cells (Konsman et al., 2004; Liu et al., 2015; Matsuwaki et al., 2014), and accordingly, 
the present data demonstrate a critical role of IL-1R1 on these cells for LPS induced fever. However, it cannot be excluded that IL-1R1s are expressed by other cell types in the brain as well, but that levels are too low to allow immunohistochemical detection (Liu et al., 2015; Vasilache et al., 2015). It is therefore possible that IL-1 $\beta$ could act also on other cells than brain endothelial cells to evoke physiological responses. The IL-1 $\beta$ that is seen in the brain, and that is strongly induced by peripheral immune challenge (e.g., Nilsberth et al., 2009b), is produced by brain cells, because only little circulating IL-1 $\beta$ can pass the blood-brain barrier (Banks et al., 1995). Here we examined the role of IL-1R1 on neurally derived cells, using IL-1R1 deletion with Cre recombinase under the Nestin promoter and enhancer that is expressed in almost all neural precursor cells (Zimmerman et al., 1994). There was little effect by the Nestin-Cre induced IL-1R1 deletion on the febrile response to LPS, with the possible exception for a statistically significant but small attenuation during the second phase of fever. It should be noted that a similar difference during the second phase of fever, although not statistically significant, was seen between LPS treated WT mice and mice with global deletion of IL-1R1, but that no such difference was seen at that time period between WT mice and mice with selective deletion of IL-1R1 in brain endothelial cells. It is hence possible that neural IL1R1s contribute to the febrile response to LPS during the second phase of fever, and could either be due to a role for peripheral nerves that was not detected after IL-1R1 deletion with the TRPV1 or HTPA promotors, or exerted by IL-1R1 signaling by neural elements in the brain parenchyma. However, in any case, their contribution, if present, is small.

\section{Conclusion}

Although IL-1 $\beta$ is a potent inducer of sickness symptoms, deletion of its transducing receptor, IL1R1 has no effect on LPS induced anorexia or stress hormone release, and attenuates, but does not abolish, LPS induced fever. The latter effect involves IL-1R1s expressed by brain endothelial cells, whereas IL-1R1s on neural cells or peripheral nerves play little, if any role. The remaining LPS induced fever in IL-1R1 deficient mice is not explained by the action of IL- 6 or TNF $\alpha$, and 
involves maintained Cox-2 mRNA and protein expression in the brain.

\section{Acknowledgements}

This study was supported by the Japan Society for the Promotion of Science (15K18800 to TM), the Swedish Medical Research Council (\#20725 to DE and \#07879 to AB), the European Research Council (ERC-starting grant to DE), the Knut and Alice Wallenberg foundation (DE), the Swedish Brain Foundation (DE and AB), the Swedish Cancer Foundation (\#213/692 to AB), and the County Council of Östergötland (DE and AB). The generation of mice with conditional deletion of IL-1R1 was funded by the Sixth Research Framework Programme of the European Union, Project MUGEN (MUGEN LSHG-CT-2005-005203) to WM and the MRC research grant (G0801296) to Nancy Rothwell, Stuart Allan and EP. We thank Dr. Yoichiro Iwakura for providing IL-1R1 KO mice.

\section{References}

Abdulaal, W.H., Walker, C.R., Costello, R., Redondo-Castro, E., Mufazalov, I.A., Papaemmanouil, A., Rothwell, N.J., Allan, S.M., Waisman, A., Pinteaux, E., Müller, W., 2016. Characterization of a conditional interleukin-1 receptor 1 mouse mutant using the Cre/LoxP system. Eur. J. Immunol. 46, 912-918.

Aiura, K., Gelfand, J.A., Burke, J.F., Thompson, R.C., Dinarello, C.A., 1993. Interleukin-1 (IL-1) receptor antagonist prevents Staphylococcus epidermidis-induced hypotension and reduces circulating levels of tumor necrosis factor and IL-1 beta in rabbits. Infect Immun $61,3342-3350$.

Alheim, K., Chai, Z., Fantuzzi, G., Hasanvan, H., Malinowsky, D., Di Santo, E., Ghezzi, P., Dinarello, C.A., Bartfai, T., 1997. Hyperresponsive febrile reactions to interleukin (IL) 1alpha and IL-1beta, and altered brain cytokine mRNA and serum cytokine levels, in IL1beta-deficient mice. Proc. Natl. Acad. Sci. USA 94, 2681-2686.

Banks, W.A., Kastin, A.J., Broadwell, R.D., 1995. Passage of cytokines across the blood-brain 
barrier. Neuroimmunomodulation 2, 241-248.

Banks, W.A., Gray, A.M., Erickson, M.A., Salameh, T.S., Damodarasamy, M., Sheibani, N., Meabon, J.S., Wing, E.E., Morofuji, Y., Cook, D.G., Reed, M.J., 2015. Lipopolysaccharide-induced blood-brain barrier disruption: roles of cyclooxygenase, oxidative stress, neuroinflammation, and elements of the neurovascular unit. J. Neuroinflamm 12, 223.

Berkenbosch, F., Schipper, J., Tilders, F.J.H., 1986. Corticotropin-releasing factor immunostaining in the rat spinal cord and medulla oblongata: an unexpected form of cross-reactivity with substance P. Brain Res. 399, 87-96.

Berkenbosch, F., van Oers, J., del Rey, A., Tilders, F., Besedovsky, H., 1987. Corticotropinreleasing factor-producing neurons in the rat activated by interleukin-1. Science 238, 524526.

Besedovsky, H., del Rey, A., Sorkin, E., Dinarello, C.A., 1986. Immunoregulatory feedback between interleukin-1 and glucocorticoid hormones. Science 233, 652-654.

Binshtok, A.M., Wang, H., Zimmermann, K., Amaya, F., Vardeh, D., Shi, L., Brenner, G.J., Ji, R.-R., Bean, B.P., Woolf, C.J., Samad, T.A., 2008. Nociceptors are interleukin-1 $\beta$ sensors. J. Neurosci. 28, 14062-14073.

Bluthé, R.-M., Layé, S., Michaud, B., Combe, C., Dantzer, R., Parnet, P., 2000. Role of interleukin- $1 \beta$ and tumour necrosis factor- $\alpha$ in lipopolysaccharide-induced sickness behaviour: a study with interleukin-1 type I receptor-deficient mice. Eur. J. Neurosci. 12, 4447-4456.

Cao, C., Matsumura, K., Yamagata, K., Watanabe, Y., 1998. Cyclooxygenase-2 is induced in brain blood vessels during fever evoked by peripheral or central administration of tumor necrosis factor. Brain Res. Mol. Brain Res. 56, 45-56.

Cartmell, T., Poole, S., Turnbull, A.V., Rothwell, N.J., Luheshi, G.N., 2000. Circulating 
interleukin-6 mediates the febrile response to localised inflammation in rats. J. Physiol. $526,653-661$.

Cavanaugh, D.J., Chesler, A.T., Jackson, A.C., Sigal, Y.M., Yamanaka, H., Grant, R., O'Donnell, D., Nicoll, R.A., Shah, N.M., Julius, D., Basbaum, A.I., 2011. Trpv1 reporter mice reveal highly restricted brain distribution and functional expression in arteriolar smooth muscle cells. J. Neurosci. 31, 5067-5077.

Chai, Z., Gatti, S., Toniatti, C., Poli, V., Bartfai, T., 1996. Interleukin (IL)-6 gene expression in the central nervous system is necessary for fever response to lipopolysaccharide or IL-1 beta: a study on IL-6-deficient mice. J. Exp. Med. 183, 311-316.

Chakravarty, S., Herkenham, M., 2005. Toll-like receptor 4 on nonhematopoietic cells sustains CNS inflammation during endotoxemia, independent of systemic cytokines. J. Neurosci. $25,1788-1796$.

Ching, S., Zhang, H., Belevych, N., He, L., Lai, W., Pu, X.A., Jaeger, L.B., Chen, Q., Quan, N., 2007. Endothelial-specific knockdown of interleukin-1 (IL-1) type 1 receptor differentially alters CNS responses to IL-1 depending on its route of administration. J. Neurosci. 27, 10476-10486.

Dinarello, C.A., 2004. Infection, fever, and exogenous and endogenous pyrogens: some concepts have changed. J. Endotoxin Res. 10, 201-222.

Dinarello, C.A., Cannon, J.G., Wolff, S.M., 1988. New concepts on the pathogenesis of fever. Rev. Infect. Dis. 10, 168-189.

Dunn, A.J., 1992. The role of interleukin-1 and tumor necrosis factor alpha in the neurochemical and neuroendocrine responses to endotoxin. Brain research bulletin 29, 807-812.

Dunn, A.J., 2000. Effects of the IL-1 Receptor antagonist on the IL-1- and endotoxin-induced activation of the HPA axis and cerebral biogenic amines in mice. Neuroimmunomodulation 7, 36-45. 
Ek, M., Engblom, D., Saha, S., Blomqvist, A., Jakobsson, P.J., Ericsson-Dahlstrand, A., 2001. Inflammatory response: pathway across the blood-brain barrier. Nature 410, 430-431.

Ek, M., Kurosawa, M., Lundeberg, T., Ericsson, A., 1998. Activation of vagal afferents after intravenous injection of interleukin-1beta: role of endogenous prostaglandins. J. Neurosci. $18,9471-9479$.

Elander, L., Engstrom, L., Hallbeck, M., Blomqvist, A., 2007. IL-1beta and LPS induce anorexia by distinct mechanisms differentially dependent on microsomal prostaglandin E synthase1. Am. J. Physiol. Regul. Integr. Comp. Physiol. 292, R258-267.

Elander, L., Engstrom, L., Ruud, J., Mackerlova, L., Jakobsson, P.J., Engblom, D., Nilsberth, C., Blomqvist, A., 2009. Inducible prostaglandin E2 synthesis interacts in a temporally supplementary sequence with constitutive prostaglandin-synthesizing enzymes in creating the hypothalamic-pituitary-adrenal axis response to immune challenge. J. Neurosci. 29, 1404-1413.

Engström, L., Ruud, J., Eskilsson, A., Larsson, A., Mackerlova, L., Kugelberg, U., Qian, H., Vasilache, A.M., Larsson, P., Engblom, D., Sigvardsson, M., Jönsson, J.-I., Blomqvist, A., 2012. Lipopolysaccharide-induced fever depends on prostaglandin E2 production specifically in brain endothelial cells. Endocrinology 153, 4849-4861.

Eskilsson, A., Matsuwaki, T., Shionoya, K., Mirrasekhian, E., Zajdel, J., Schwaninger, M., Engblom, D., Blomqvist, A., 2017. Immune-induced fever is dependent on local but not generalized prostaglandin E2 synthesis in the brain. J. Neurosci. 37, 5035-5044.

Eskilsson, A., Mirrasekhian, E., Dufour, S., Schwaninger, M., Engblom, D., Blomqvist, A., 2014. Immune-induced fever is mediated by IL-6 receptors on brain endothelial cells coupled to STAT3-dependent induction of brain endothelial prostaglandin synthesis. J. Neurosci. 34, 15957-15961.

Fantuzzi, G., Dinarello, C.A., 1996. The inflammatory response in interleukin-1 beta-deficient 
mice: comparison with other cytokine-related knock-out mice. J. Leukoc. Biol. 59, 489493.

Gaykema, R.P.A., Goehler, L.E., Hansen, M.K., Maier, S.F., Watkins, L.R., 2000.

Subdiaphragmatic vagotomy blocks interleukin-1 beta-induced fever but does not reduce IL-1 beta levels in the circulation. Auton. Neurosci-Basic Clin. 85, 72-77.

Glaccum, M.B., Stocking, K.L., Charrier, K., Smith, J.L., Willis, C.R., Maliszewski, C., Livingston, D.J., Peschon, J.J., Morrissey, P.J., 1997. Phenotypic and functional characterization of mice that lack the type I receptor for IL-1. J. Immunol. 159, 33643371.

Goshen, I., Yirmiya, R., Iverfeldt, K., Weidenfeld, J., 2003. The role of endogenous interleukin-1 in stress-induced adrenal activation and adrenalectomy-induced adrenocorticotropic hormone hypersecretion. Endocrinology 144, 4453-4458.

Harden, L.M., Plessis, I.d., Poole, S., Laburn, H.P., 2008. Interleukin (IL)-6 and IL-1[beta] act synergistically within the brain to induce sickness behavior and fever in rats. Brain Behav. Immun. 22, 838-849.

Hellerstein, M.K., Meydani, S.N., Meydani, M., Wu, K., Dinarello, C.A., 1989. Interleukin-1induced anorexia in the rat. Influence of prostaglandins. J. Clin. Invest. 84, 228-235.

Horai, R., Asano, M., Sudo, K., Kanuka, H., Suzuki, M., Nishihara, M., Takahashi, M., Iwakura, Y., 1998. Production of mice deficient in genes for interleukin (IL)-1alpha, IL-1beta, IL1alpha/beta, and IL-1 receptor antagonist shows that IL-1beta is crucial in turpentineinduced fever development and glucocorticoid secretion. J. Exp. Med. 187, 1463-1475. Jesus, A.A., Goldbach-Mansky, R., 2014. IL-1 blockade in autoinflammatory syndromes. Annu. Rev. Med. 65, 223-244.

Joosten, L.A.B., Van De Veerdonk, F.L., Vonk, A.G., Boerman, O.C., Keuter, M., Fantuzzi, G., Verschueren, I., Van Der Poll, T.O.M., Dinarello, C.A., Kullberg, B.J., Van Der Meer, 
J.W.M., Netea, M.G., 2010. Differential susceptibility to lethal endotoxaemia in mice deficient in IL-1 $\alpha$, IL-1 $\beta$ or IL-1 receptor type I. APMIS 118, 1000-1007.

Konsman, J.P., Luheshi, G.N., Bluthe, R.M., Dantzer, R., 2000. The vagus nerve mediates behavioural depression, but not fever, in response to peripheral immune signals; a functional anatomical analysis. Eur. J. Neurosci. 12, 4434-4446.

Konsman, J.P., Vigues, S., Mackerlova, L., Bristow, A., Blomqvist, A., 2004. Rat brain vascular distribution of interleukin-1 type-1 receptor immunoreactivity: Relationship to patterns of inducible cyclooxygenase expression by peripheral inflammatory stimuli. J. Comp. Neurol. 472, 113-129.

Kozak, W., Conn, C.A., Klir, J.J., Wong, G.H., Kluger, M.J., 1995. TNF soluble receptor and antiserum against TNF enhance lipopolysaccharide fever in mice. Am. J. Physiol. 269, R23-29.

Kozak, W., Kluger, M.J., Soszynski, D., Conn, C.A., Rudolph, K., Leon, L.R., Zheng, H., 1998. IL-6 and IL-1 beta in fever. Studies using cytokine-deficient (knockout) mice. Ann. N. Y. Acad. Sci. 856, 33-47.

Labow, M., Shuster, D., Zetterstrom, M., Nunes, P., Terry, R., Cullinan, E.B., Bartfai, T., Solorzano, C., Moldawer, L.L., Chizzonite, R., McIntyre, K.W., 1997. Absence of IL-1 signaling and reduced inflammatory response in IL-1 type I receptor-deficient mice. J. Immunol. 159, 2452-2461.

Leon, L.R., Conn, C.A., Glaccum, M., Kluger, M.J., 1996. IL-1 type I receptor mediates acute phase response to turpentine, but not lipopolysaccharide, in mice. Am. J. Physiol. 271, R1668-1675.

Leon, L.R., White, A.A., Kluger, M.J., 1998. Role of IL-6 and TNF in thermoregulation and survival during sepsis in mice. Am. J. Physiol. 275, R269-277.

Liu, X., Yamashita, T., Chen, Q., Belevych, N., McKim, D.B., Tarr, A.J., Coppola, V., Nath, N., 
Nemeth, D.P., Syed, Z.W., Sheridan, J.F., Godbout, J.P., Zuo, J., Quan, N., 2015.

Interleukin 1 type 1 receptor restore: a genetic mouse model for studying interleukin 1 receptor-mediated effects in specific cell types. J. Neurosci. 35, 2860-2870.

Long, N.C., Kunkel, S.L., Vander, A.J., Kluger, M.J., 1990a. Antiserum against tumor necrosis factor enhances lipopolysaccharide fever in rats. Am. J. Physiol. 258, R332-337.

Long, N.C., Otterness, I., Kunkel, S.L., Vander, A.J., Kluger, M.J., 1990b. Roles of interleukin 1 beta and tumor necrosis factor in lipopolysaccharide fever in rats. Am. J. Physiol. 259, R724-728.

Luheshi, G., Miller, A.J., Brouwer, S., Dascombe, M.J., Rothwell, N.J., Hopkins, S.J., 1996. Interleukin-1 receptor antagonist inhibits endotoxin fever and systemic interleukin-6 induction in the rat. Am. J. Physiol. Endocrinol. Metab. 270, E91-E95.

Luheshi, G.N., Bluthe, R.M., Rushforth, D., Mulcahy, N., Konsman, J.P., Goldbach, M., Dantzer, R., 2000. Vagotomy attenuates the behavioural but not the pyrogenic effects of interleukin-1 in rats. Auton. Neurosci. 85, 127-132.

MacParland, S.A., Ma, X.-Z., Chen, L., Khattar, R., Cherepanov, V., Selzner, M., Feld, J.J., Selzner, N., McGilvray, I.D., 2016. Lipopolysaccharide and tumor necrosis factor alpha inhibit interferon signaling in hepatocytes by increasing ubiquitin-like protease 18 (USP18) expression. J. Virol. 90, 5549-5560.

Matsuwaki, T., Eskilsson, A., Kugelberg, U., Jönsson, J.-I., Blomqvist, A., 2014. Interleukin-1 $\beta$ induced activation of the hypothalamus-pituitary-adrenal axis is dependent on interleukin1 receptors on non-hematopoietic cells. Brain Behav. Immun. 40, 166-173.

Mbonye, U., Song, I., 2009. Posttranscriptional and posttranslational determinants of cyclooxygenase expression. BMB Rep. 42, 552-560.

Medvedev, A.E., Kopydlowski, K.M., Vogel, S.N., 2000. Inhibition of lipopolysaccharideinduced signal transduction in endotoxin-tolerized mouse macrophages: dysregulation of 
cytokine, chemokine, and toll-like receptor 2 and 4 gene expression. J. Immunol. 164, 5564-5574.

Morrow, J.D., Opp, M.R., 2005. Diurnal variation of lipopolysaccharide-induced alterations in sleep and body temperature of interleukin-6-deficient mice. Brain Behav. Immun. 19, 4051.

Nilsberth, C., Elander, L., Hamzic, N., Norell, M., Lonn, J., Engstrom, L., Blomqvist, A., 2009a. The role of interleukin- 6 in lipopolysaccharide-induced fever by mechanisms independent of prostaglandin E2. Endocrinology 150, 1850-1860.

Nilsberth, C., Hamzic, N., Norell, M., Blomqvist, A., 2009b. Peripheral lipopolysaccharide administration induces cytokine mRNA expression in the viscera and brain of feverrefractory mice lacking microsomal prostaglandin E synthase-1. J. Neuroendocrinol. 21, $715-721$.

Nilsson, A., Wilhelms, D.B., Mirrasekhian, E., Jaarola, M., Blomqvist, A., Engblom, D., 2017. Inflammation-induced anorexia and fever are elicited by distinct prostaglandin dependent mechanisms, whereas conditioned taste aversion is prostaglandin independent. Brain Behav. Immun. 61, 236-243.

Ohlsson, K., Bjork, P., Bergenfeldt, M., Hageman, R., Thompson, R.C., 1990. Interleukin-1 receptor antagonist reduces mortality from endotoxin shock. Nature 348, 550-552.

Pietri, T., Eder, O., Blanche, M., Thiery, J.P., Dufour, S., 2003. The human tissue plasminogen activator-Cre mouse: a new tool for targeting specifically neural crest cells and their derivatives in vivo. Dev. Biol. 259, 176-187.

Qian, J., Zhu, L., Li, Q., Belevych, N., Chen, Q., Zhao, F., Herness, S., Quan, N., 2012. Interleukin-1R3 mediates interleukin-1-induced potassium current increase through fast activation of Akt kinase. Proc. Natl. Acad. Sci. U S A 109, 12189-12194.

Quan, N., 2014. In-depth conversation: Spectrum and kinetics of neuroimmune afferent 
pathways. Brain Behav. Immun. 40, 1-8.

Reyes, T.M., Walker, J.R., DeCino, C., Hogenesch, J.B., Sawchenko, P.E., 2003. Categorically distinct acute stressors elicit dissimilar transcriptional profiles in the paraventricular nucleus of the hypothalamus. J. Neurosci. 23, 5607-5616.

Ridder, D.A., Lang, M.-F., Salinin, S., Röderer, J.-P., Struss, M., Maser-Gluth, C., Schwaninger, M., 2011. TAK1 in brain endothelial cells mediates fever and lethargy. J. Exp. Med. 208, $2615-2623$.

Romanovsky, A.A., 2000. Thermoregulatory manifestations of systemic inflammation: lessons from vagotomy. Auton. Neurosci. 85, 39-48.

Ross, G., Roth, J., Störr, B., Voigt, K., Zeisberger, E., Afferent nerves are involved in the febrile response to injection of LPS into artificial subcutaneous chambers in guinea pigs. Physiol. Behav. 71, 305-313.

Rummel, C., Barth, S.W., Voss, T., Korte, S., Gerstberger, R., Hübschle, T., Roth, J., 2005. Localized vs. systemic inflammation in guinea pigs: a role for prostaglandins at distinct points of the fever induction pathways? Am. J. Physiol. Regul. Integr. Comp. Physiol. 289, R340-R347.

Rummel, C., Sachot, C., Poole, S., Luheshi, G.N., 2006. Circulating interleukin-6 induces fever through a STAT3-linked activation of COX-2 in the brain. Am. J. Physiol. Regul. Integr. Comp. Physiol. 291, R1316-1326.

Smith, B.K., Kluger, M.J., 1992. Human IL-1 receptor antagonist partially suppresses LPS fever but not plasma levels of IL-6 in Fischer rats. Am. J. Physiol. 263, R653-655.

Tollner, B., Roth, J., Storr, B., Martin, D., Voigt, K., Zeisberger, E., 2000. The role of tumor necrosis factor (TNF) in the febrile and metabolic responses of rats to intraperitoneal injection of a high dose of lipopolysaccharide. Pflugers Arch. 440, 925-932.

Turek, V.F., Olster, D.H., Ettenberg, A., Carlisle, H.J., 2005. The behavioral thermoregulatory 
response of febrile female rats is not attenuated by vagotomy. Pharmacol. Biochem. Behav. 80, 115-121.

Ueda, O., Tateishi, H., Higuchi, Y., Fujii, E., Kato, A., Kawase, Y., Wada, N.A., Tachibe, T., Kakefuda, M., Goto, C., Kawaharada, M., Shimaoka, S., Hattori, K., Jishage, K.-i., 2013. Novel genetically-humanized mouse model established to evaluate efficacy of therapeutic agents to human interleukin-6 receptor. Sci. Rep. 3, 1196.

Vasilache, A.M., Qian, H., Blomqvist, A., 2015. Immune challenge by intraperitoneal administration of lipopolysaccharide directs gene expression in distinct blood-brain barrier cells toward enhanced prostaglandin E2 signaling. Brain Behav. Immun. 48, 31-41.

Wakabayashi, G., Gelfand, J.A., Burke, J.F., Thompson, R.C., Dinarello, C.A., 1991. A specific receptor antagonist for interleukin 1 prevents Escherichia coli-induced shock in rabbits. FASEB J. 5, 338-343.

Watkins, L.R., Goehler, L.E., Relton, J.K., Tartaglia, N., Silbert, L., Martin, D., Maier, S.F., 1995. Blockade of interleukin-1 induced hyperthermia by subdiaphragmatic vagotomy: evidence for vagal mediation of immune-brain communication. Neurosci. Lett. 183, 27-31. Wilhelms, D.B., Kirilov, M., Mirrasekhian, E., Eskilsson, A., Kugelberg, U.Ö., Klar, C., Ridder, D., Herschman, H.R., Schwaninger, M., Blomqvist, A., Engblom, D., 2014. Deletion of prostaglandin E2 synthesizing enzymes in brain endothelial cells attenuates inflammatory fever. J. Neurosci. 34, 11684-11690.

Yamagata, K., Matsumura, K., Inoue, W., Shiraki, T., Suzuki, K., Yasuda, S., Sugiura, H., Cao, C., Watanabe, Y., Kobayashi, S., 2001. Coexpression of microsomal-type prostaglandin E synthase with cyclooxygenase-2 in brain endothelial cells of rats during endotoxininduced fever. J. Neurosci. 21, 2669-2677.

Zimmerman, L., Lendahl, U., Cunningham, M., McKay, R., Parr, B., Gavin, B., Mann, J., Vassileva, G., McMahon, A., 1994. Independent regulatory elements in the nestin gene 
Matsuwaki et al., p. 30

direct transgene expression to neural stem cells or muscle precursors. Neuron 12, 11-24. 


\section{Legends to figures}

Figure 1. Levels (means \pm SEM) of the pro-inflammatory cytokines TNF $\alpha$ (A), IL-6 (B) and IL-1 $\beta$ (C) in plasma of wild type (WT) and IL-1R1 knockout (KO) mice at 1, 3 and $6 \mathrm{~h}$ after intraperitoneal injection of LPS. $n=5-6$.

Figure 2. Food intake (means \pm SEM) during $24 \mathrm{~h}$ in wild type (WT) and IL-1R1 knockout (KO) mice injected intraperitoneally with a low (A) and a moderate dose (B) of LPS or saline. $n=7-10$.

Figure 3. HPA-axis response to intraperitoneally injected LPS in wild type (WT) and IL-1R1 knockout (KO) mice 1, 3 and $6 \mathrm{~h}$ after injection of LPS or saline. A, B: ACTH (A) and corticosterone $(B)$ in plasma (means \pm SEM). C: Expression of Fos protein in the paraventricular nucleus of the hypothalamus. Scale bar $=100 \mu \mathrm{m}$. In (A) and (B), $n=5-6$ in the saline treated groups, and $n=7-9$ in the LPS treated groups.

Figure 4. Effect of IL-1R1 deletion/inhibition on the febrile response to LPS. Solid lines represent mean, and dotted lines SEM. A: Wild type (WT) and IL-1R1 knockout (KO) mice injected intraperitoneally with LPS or saline. *, **, and *** indicate $P<0.05,0.01$, and 0.001 between WT mice and IL-1R1 KO mice treated with LPS, and \#, \#\#, and \#\#\# indicate $P<0.05,0.01$, and 0.001 between KO mice treated with LPS and saline, respectively. $n=7-9$. B: Wild type mice treated with the IL-1R1 inhibitor anakinra or vehicle, and injected intraperitoneally with LPS or saline. * indicates $P<0.05$ between anakinra treated and vehicle treated mice injected with LPS, and \#, and \#\# indicate $P<0.05$, and 0.01 between anakinra treated mice injected with LPS and saline, respectively. $n=8$, except for the vehicle + saline group in which $n=5$ ).

Figure 5. Effects of the TNF $\alpha$ antibody etanercept (A) and the IL-6 receptor antibody tocilizumab (B) on the febrile response to LPS. Solid lines represent mean, and dotted lines SEM. In (A), \#, and \#\# indicate $P<0.05$, and 0.01 , between LPS injected IL-1R1 KO mice treated with etanercept and saline, respectively. $n=8-12$ in (A), and 6-8 in (B). 
Figure 6. Febrile response to LPS in mice with IL-1R1 deletion selectively in (A) brain endothelial cells, (B) neural cells, (C) neural crest derivates, and (D) TRPV1 expressing cells, including nociceptive C-fibers. Solid lines represent mean, and dotted lines SEM. WT mice are IL-1R1 $1^{\mathrm{fl} / \mathrm{fl}}$ littermates. * indicates $P<0.05$ between WT mice and IL-1R1 KO mice. A: $n=16$ for LPS treated WT and IL-1R1 KO mice, and $n=30$ for saline treated mice. B: $n=14$ and 12 for LPS treated WT and IL-1R1 KO mice, and $n=26$ for saline treated mice. C: $n=7$ and 8 for LPS treated WT and IL-1R1 KO mice, and $n=15$ for saline treated mice. D: $n=14$ for LPS treated WT and IL-1R1 KO mice, and $n=30$ for saline treated mice.

Figure 7: $\mathrm{PGE}_{2}$ levels in cerebrospinal fluid (CSF) (A) and induced expression in the hypothalamus of PG synthesizing enzymes (B-E) and of the IL-6 receptor alpha (F) in WT and IL-1R1 KO mice (mean $\pm \mathrm{SEM}) .{ }^{*}$ in $(\mathrm{A})$ indicates $P<0.05$. Micrographs in $(\mathrm{C})$ show immunohistochemical staining for Cox-2. Scale bar $=50 \mu \mathrm{m}$. Data in (F) are from 3 h post LPS injection. A: $n=8-12$ for LPS treated mice, and $n=4$ or 5 for saline treated mice. B, D, E, and F: $n=6-7$ for all treatment groups. 

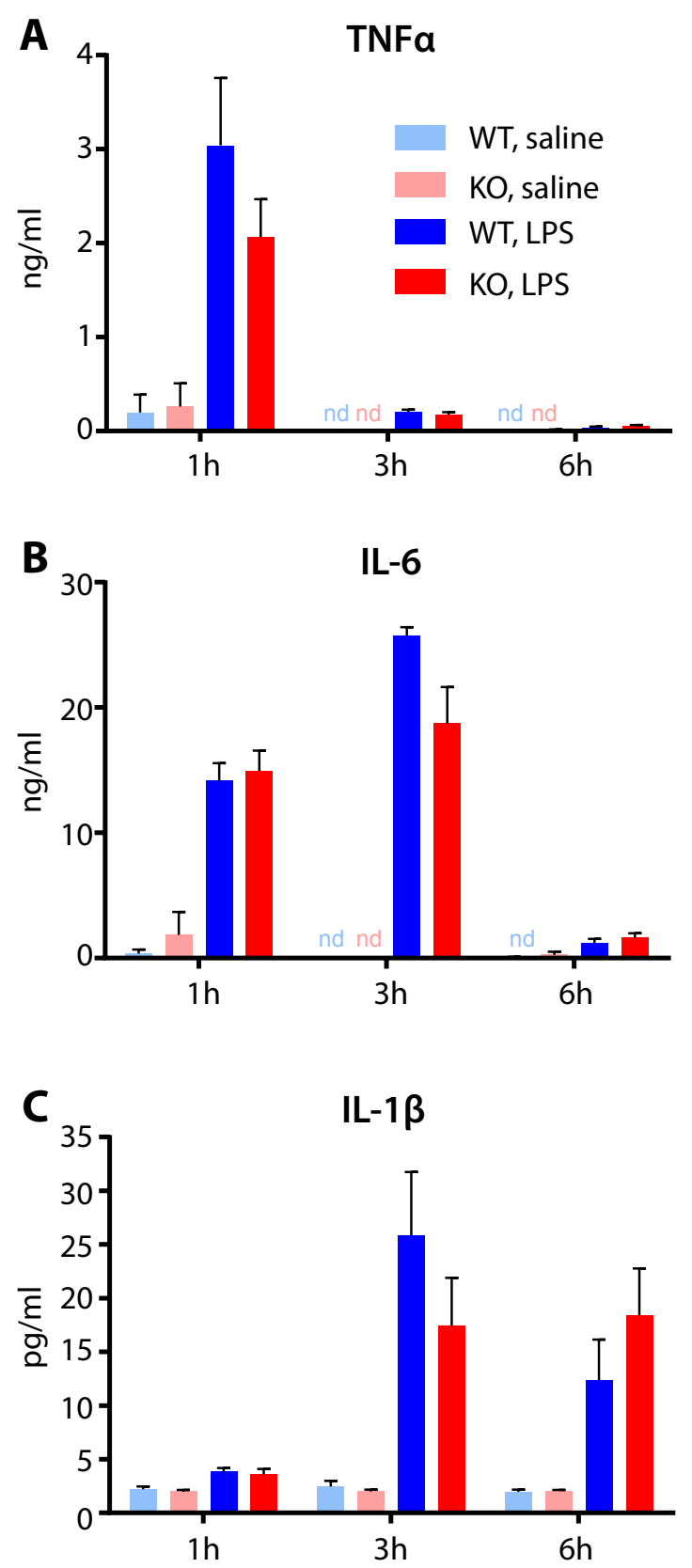

Figure 1 

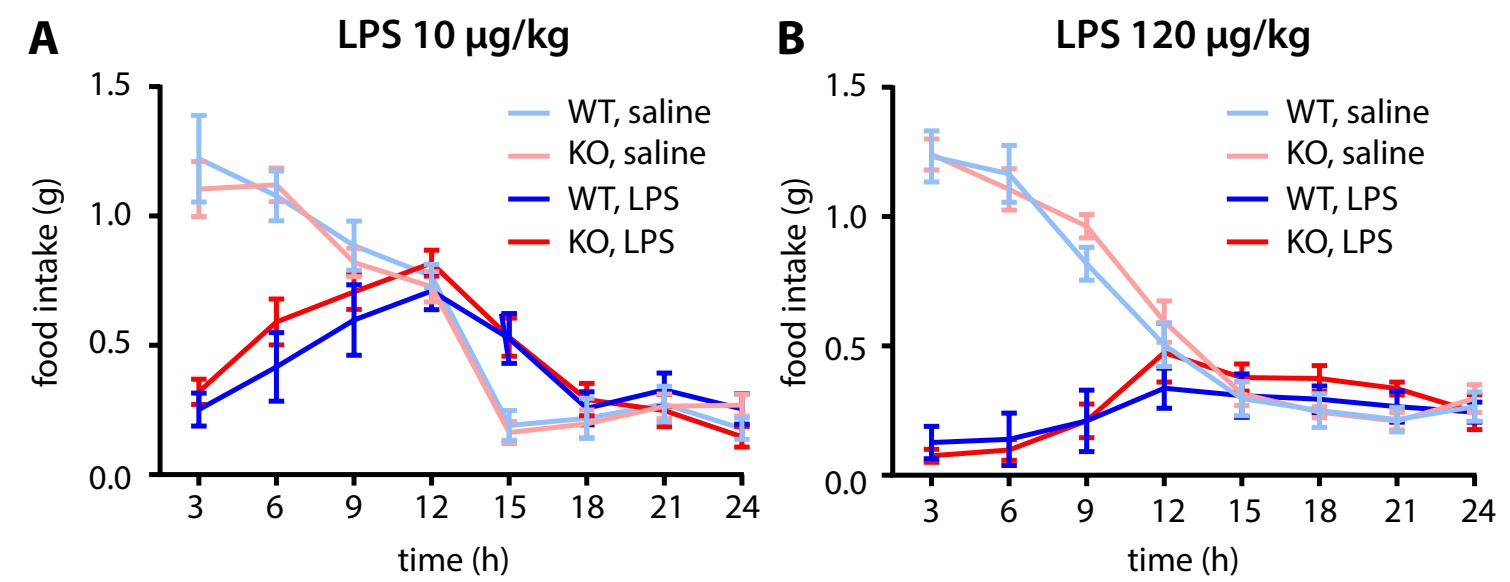

Figure 2 
A

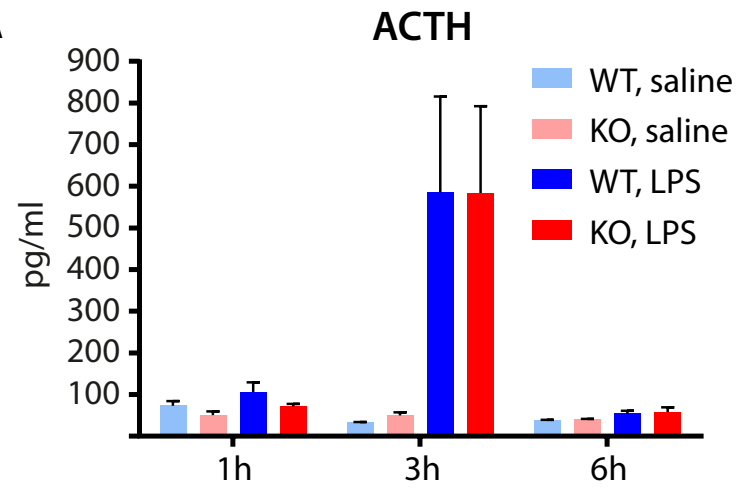

C
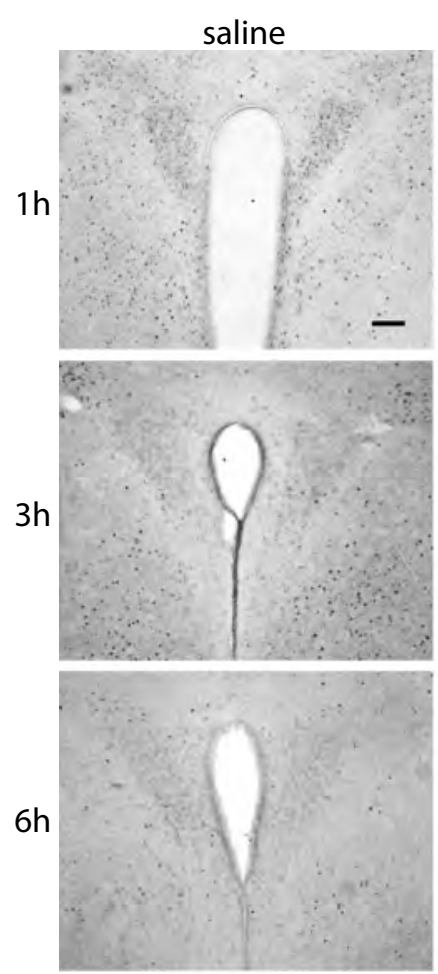

WT
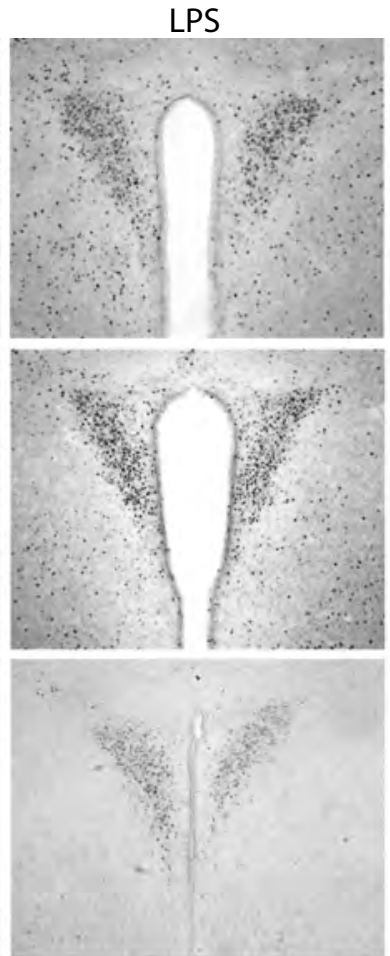

B

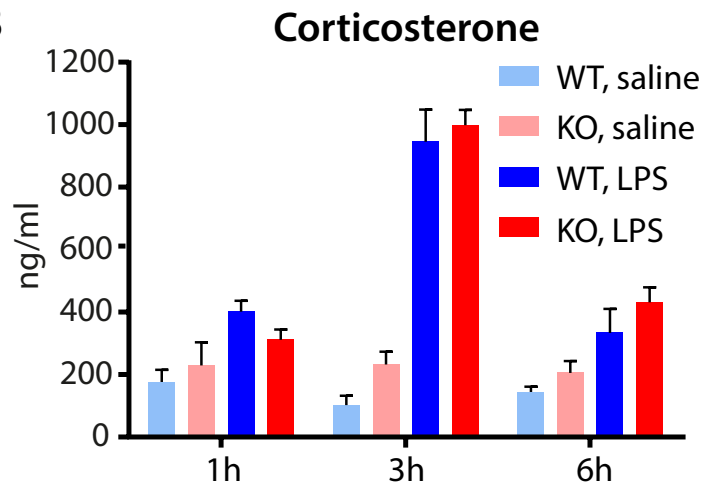

KO
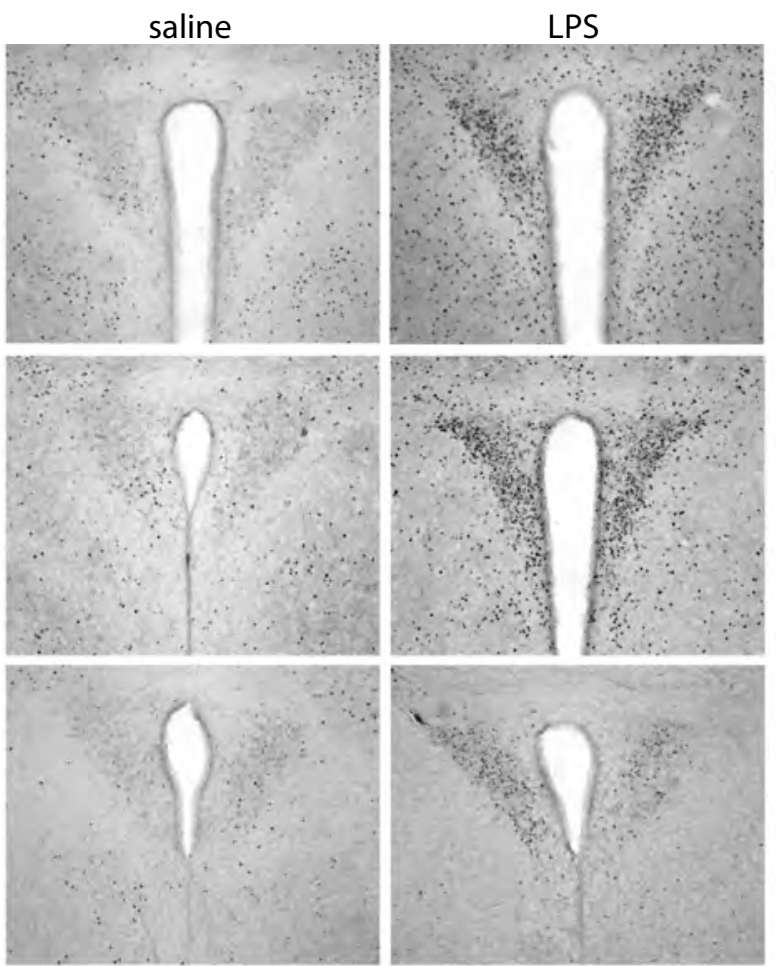

Figure 3 
A

IL-1R1KO

- WT, LPS

- KO, LPS

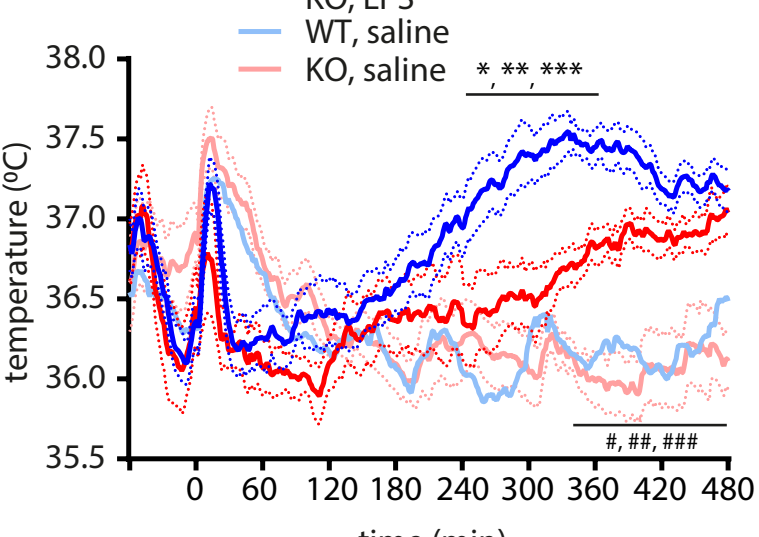

time (min)
B

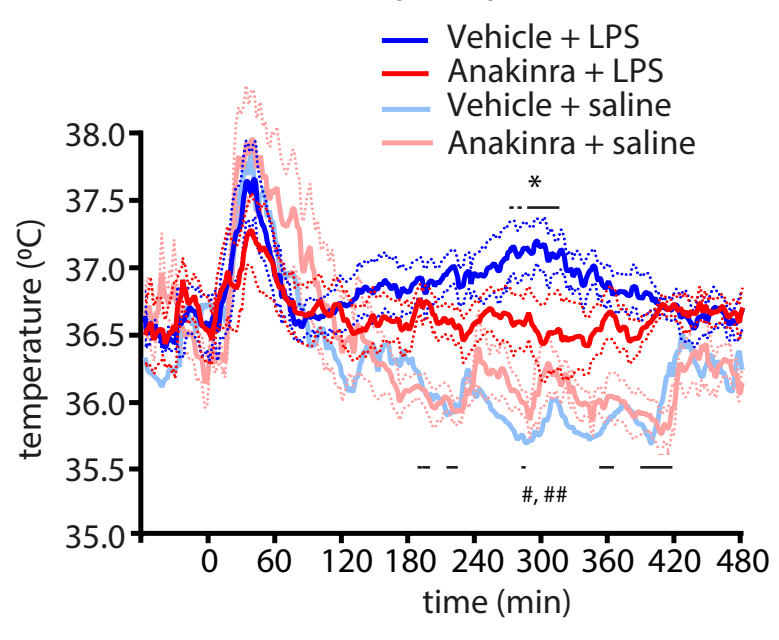

Figure 4 

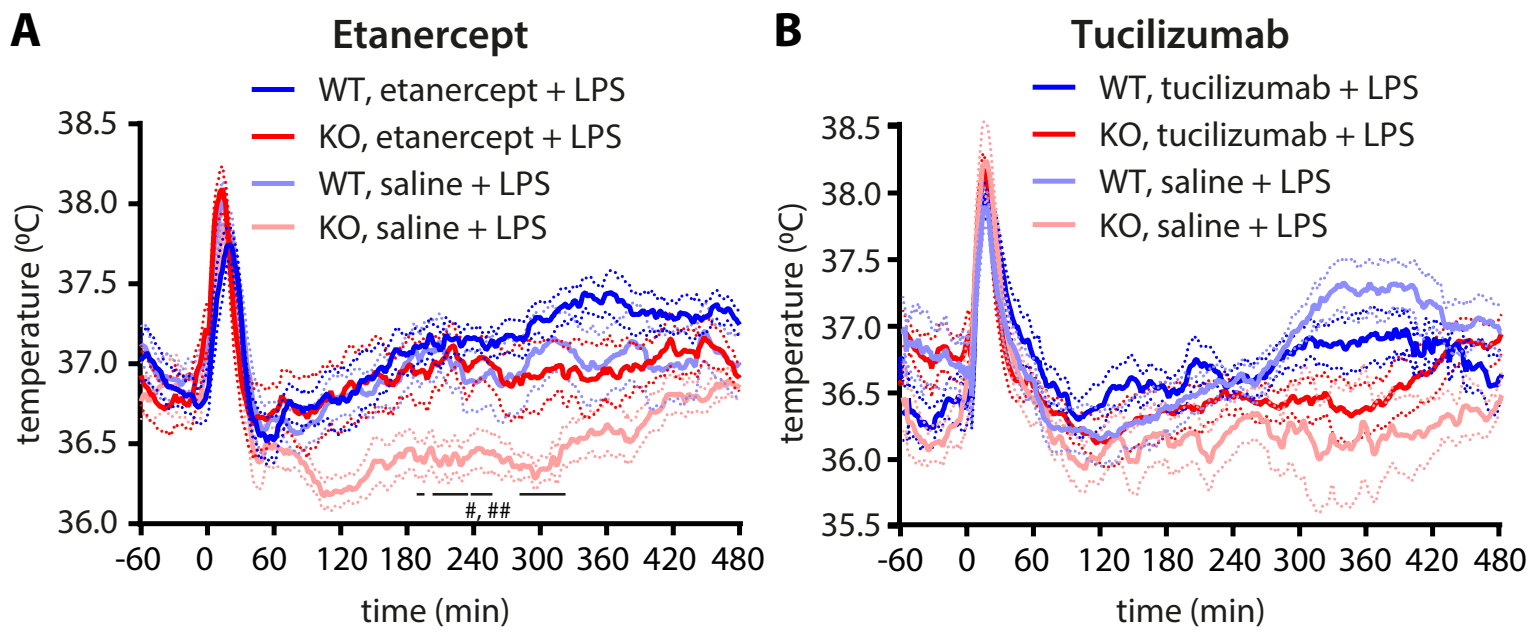

Figure 5 

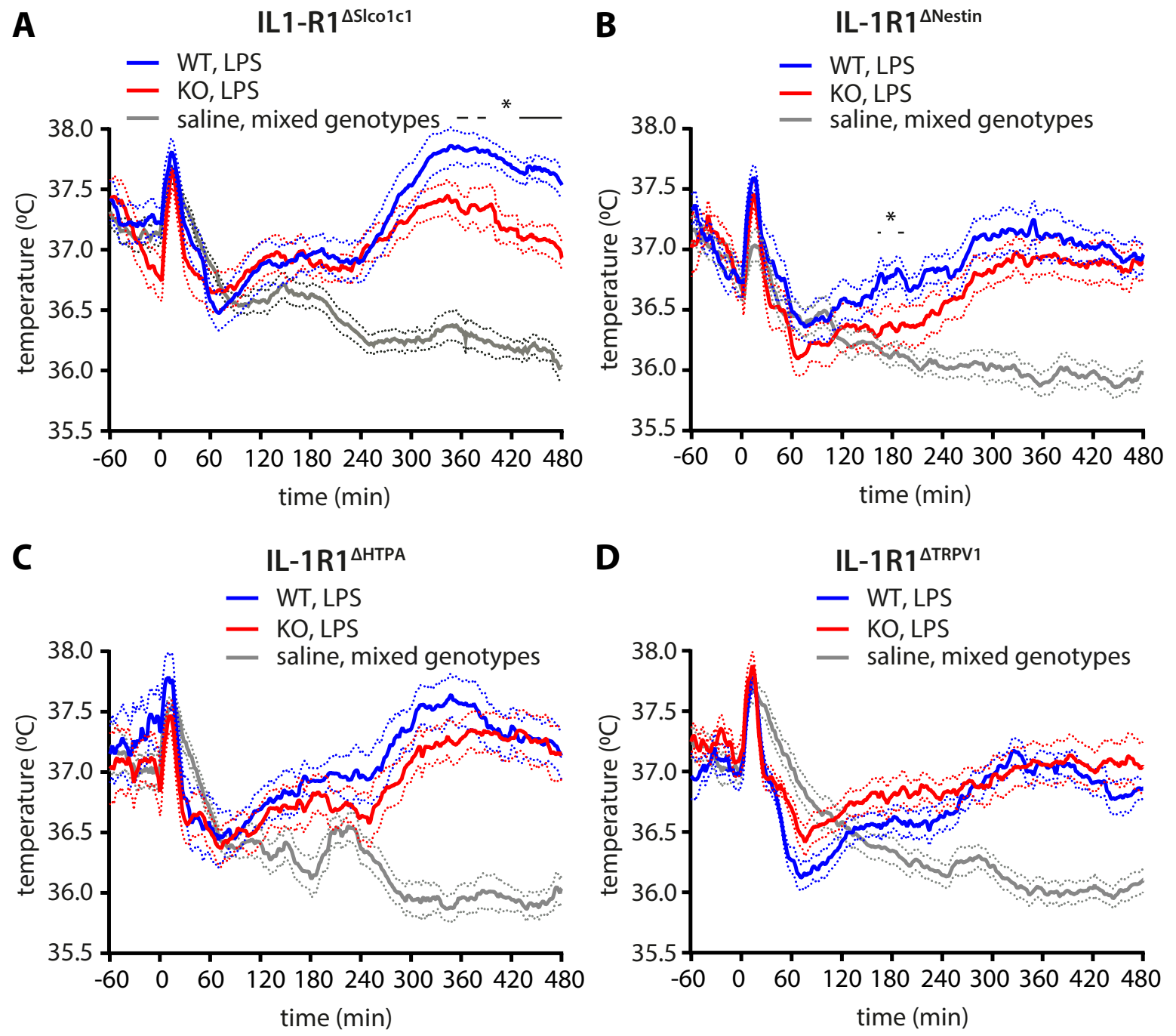

Figure 6 
A

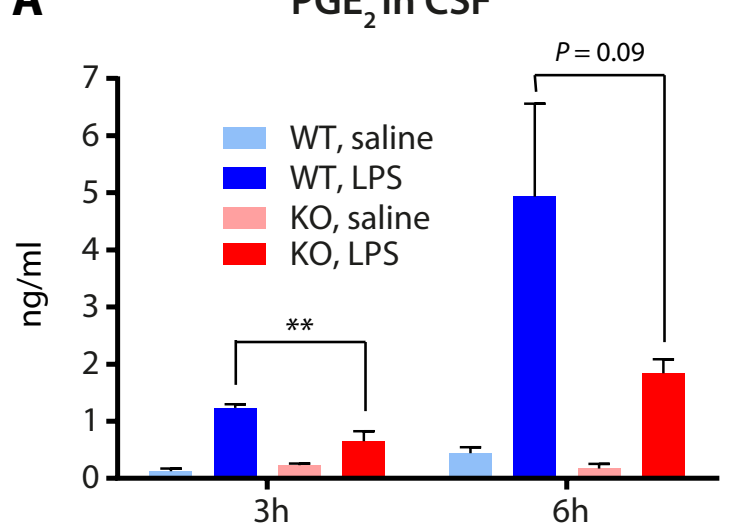

C

Cox-2
B

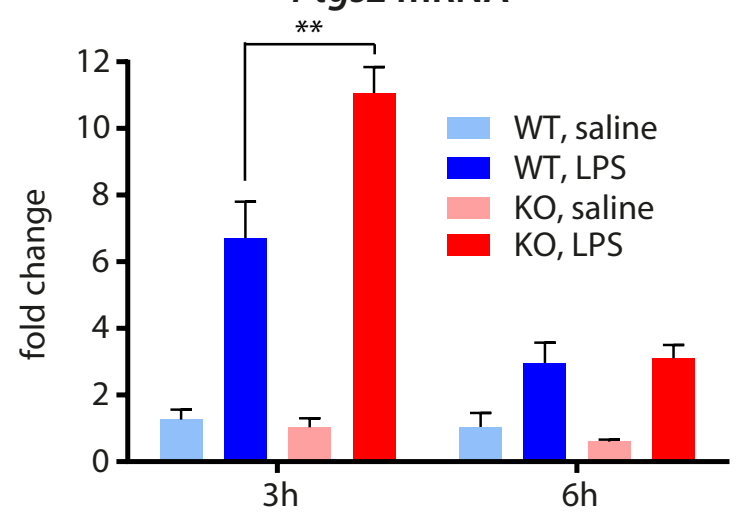

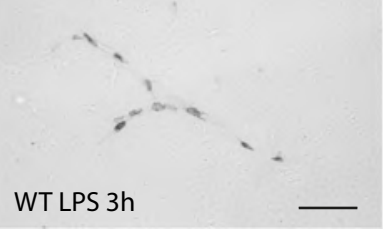

D

Ptgs1 mRNA

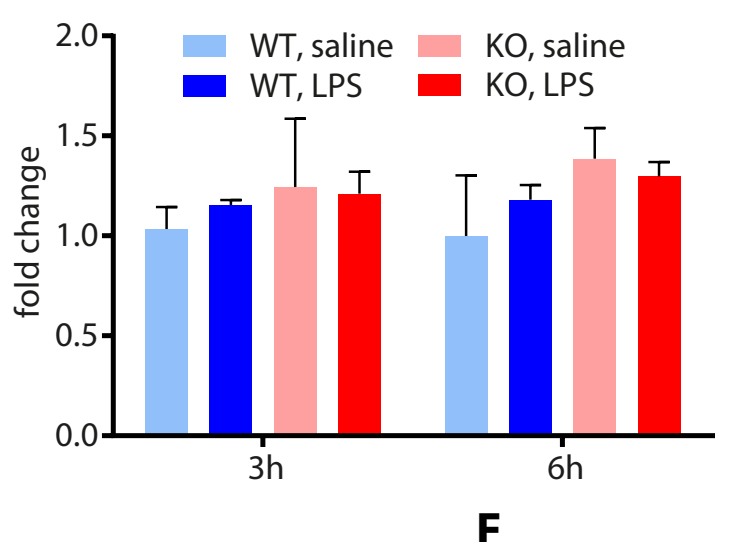

F

WT LPS $6 \mathrm{~h}$

E

E Ptges mRNA

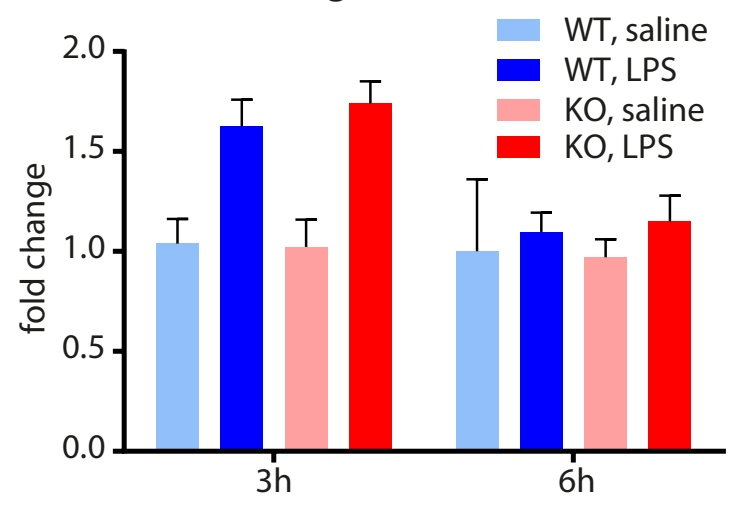

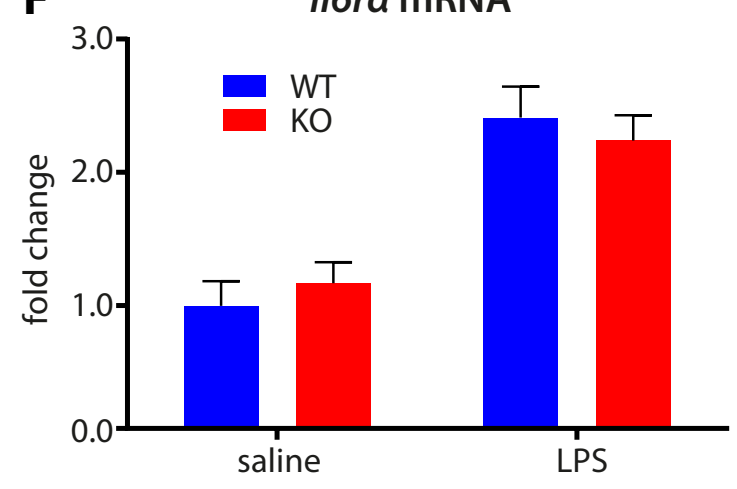

Figure 7 

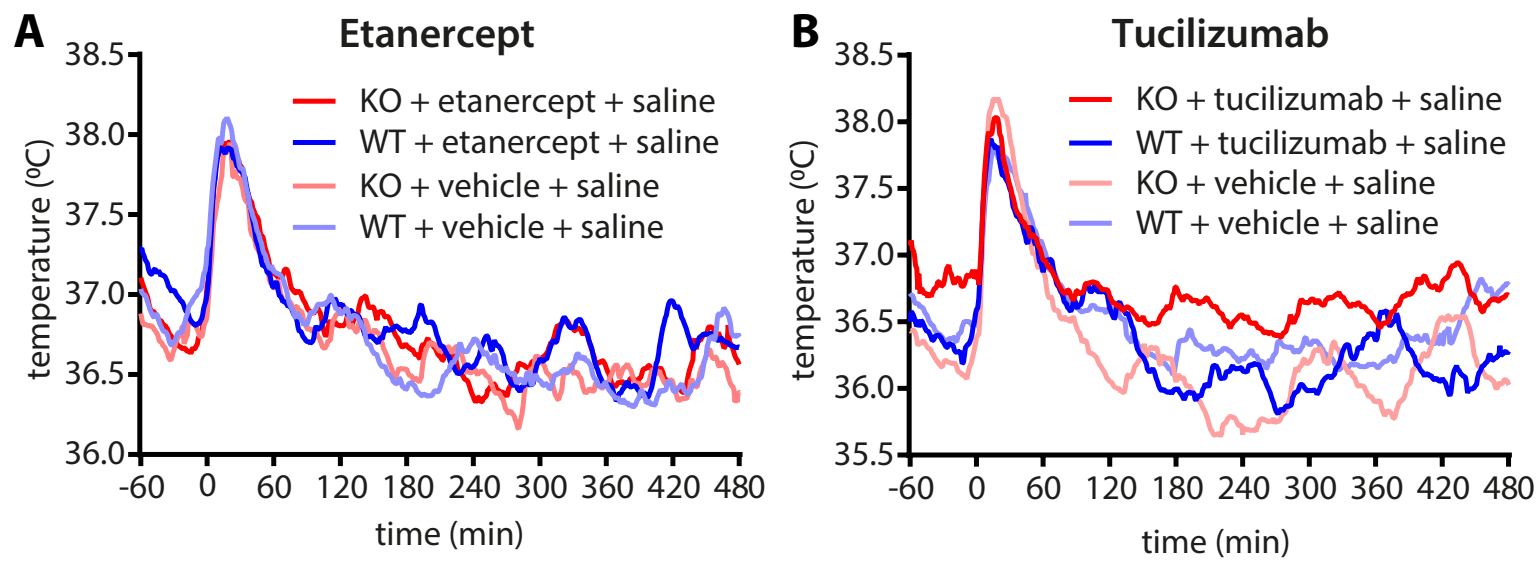

Supplementary figure 1 


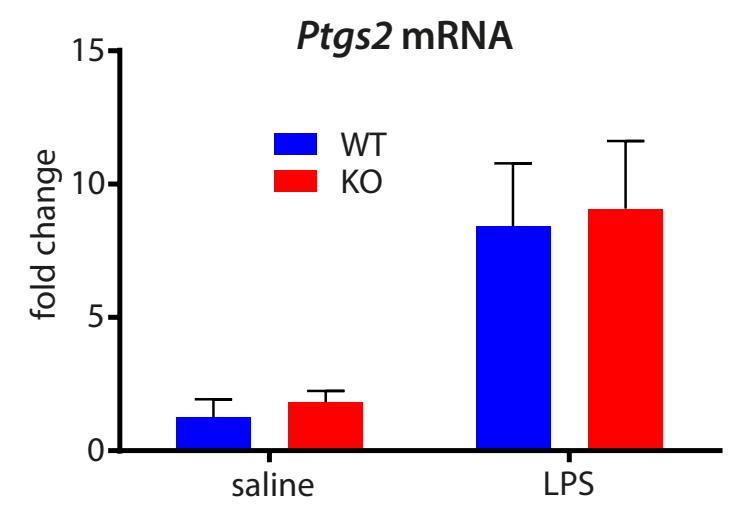

Supplementary figure 2 